\title{
Simulation of the hydrodynamic behaviour of a Mediterranean reservoir under different climate change and management scenarios
}

\author{
Jordi PRATS, ${ }^{1 *}$ Marie-José SALENÇON, ${ }^{2}$ Magali GANT, ${ }^{2}$ Pierre-Alain DANIS ${ }^{3}$ \\ ${ }^{1}$ Irstea, UR RECOVER, HYNES (Irstea-EDF R\&D), centre d'Aix-en-Provence, 3275 Route Cézanne, 13182 Aix-en-Provence; ${ }^{2}$ EDF \\ R\&D, HYNES (Irstea-EDF R\&D) Laboratoire National d'Hydraulique et Environnement, 6 quai Watier, BP 49, 78401 Chatou; ${ }^{3}$ Agence \\ Française pour la Biodiversité, Pôle AFB-Irstea Hydroécologie des plans d'eau, 3275 Route Cézanne, 13182 Aix-en-Provence, France \\ *Corresponding author: jordi.prats@irstea.fr
}

\begin{abstract}
One of the most important current issues in the management of lakes and reservoirs is the prediction of global climate change effects to determine appropriate mitigation and adaptation actions. In this paper we analyse whether management actions can limit the effects of climate change on water temperatures in a reservoir. For this, we used the model EOLE to simulate the hydrodynamic and thermal behaviour of the reservoir of Bimont (Provence region, France) in the medium term (2036-2065) and in the long term (2066-2095) using regionalised projections by the model CNRM-CERFACS-CNRM-CM5 under the emission scenarios RCP 4.5 and RCP 8.5. Water temperature projections were compared to simulations for the reference period 1993-2013, the longest period for which we had year-long data for both hydrology and meteorology. We calibrated the model using profile measurements for the period 2010-2011 and we carried an extensive validation and assessment of model performance. In fact, we validated the model using profile measurements for $2012-2014$, obtaining a root mean square error of $1.08^{\circ} \mathrm{C}$ and mean bias of $-0.11^{\circ} \mathrm{C}$, and we assured the consistency of model simulations in the long term by comparing simulated surface temperature to satellite measurements for 1999-2013. We assessed the effect of the use of synthetic input data instead of measured input data by comparing simulations made using both kinds of data for the reference period. Using synthetic data resulted in slightly lower $\left(-0.3^{\circ} \mathrm{C}\right)$ average and maximum epilimnion temperatures, a somewhat deeper thermocline, and slightly higher evaporation ( $+7 \%)$. To investigate the effect of different management strategies, we considered three management scenarios: i) bottom outlet and present water level; ii) bottom outlet and elevated water level; and iii) surface outlet and elevated water level. According to the simulations, the reservoir of Bimont will have a low rate of warming of the epilimnion of $0.009-0.024^{\circ} \mathrm{C} \cdot \mathrm{yr}^{-1}$, but a rapid hypolimnion warming of 0.013 $0.028^{\circ} \mathrm{C} \cdot \mathrm{yr}^{-1}$. The increase in surface temperatures will augment evaporation. However, the length of the stratification period and the thermocline depth are not expected to change. Elevating the water level and using a surface outlet in the reservoir of Bimont, would result in reductions of surface temperature of a similar magnitude as the expected increase because of climate change.
\end{abstract}

Key words: Climate change; hydrodynamics; management scenarios; Mediterranean area; reservoir; water temperature.

Received: August 2016. Accepted: July 2017

\section{INTRODUCTION}

In the Mediterranean area, water is a scarce resource, especially in the summer season (Gasith and Resh, 1999). Good management of the resource is thus essential, not only regarding quantity, but also about ecological and water quality. One of the most important current issues in the management of lakes and reservoirs is the prediction of global climate change effects to determine appropriate mitigation and adaptation actions. Global climate change has changed the thermal behaviour of lakes and reservoirs, increasing water temperatures, deepening the thermocline and lengthening the stratification period (Schindler, 1997; Ambrosetti and Barbanti, 1999; Livingstone, 2003; Ambrosetti et al., 2006). Different modelling works expect these trends to continue in the future (Danis et al., 2004; Fang and Stefan, 2009; Weinberger and Vetter, 2012; Hetherington et al., 2015).

Water temperature is an important variable in freshwa- ter ecosystems that can affect from freshwater organisms physiology to vital cycles and community composition (Daufresne and Boet, 2007; Cid et al., 2008; YvonDurocher et al., 2012). In addition, the hydrodynamic behaviour of a lake or reservoir determines its water quality. The thermal and hydrodynamic behaviour of a reservoir depends on external driving factors (hydrology, meteorology), that can be affected by climate change, and internal characteristics of the water body (depth of the inlets and outlets, morphometry, reservoir management), that can be modified by purposeful human intervention. The effects of such alterations can be investigated through the use of process-based hydrodynamic models (Palau, 2006; Ma et al., 2008; Marcé et al., 2010), as mathematical representations of the studied system and tools that reflect the modeller's understanding of its functioning (Robson, 2014).

Process-based models have been used to predict climate change effects on lakes and reservoirs for over two decades 
(Chang et al., 1992; Fang and Stefan, 1994). Modelling studies on lakes have centred on the prediction of effects on temperature and stratification dynamics, oxygen concentration, water quality, and phytoplankton or fish dynamics (Fang et al., 2012; Bayer et al., 2013; Trolle et al., 2014; Missaghi et al., 2017). In the case of reservoirs, climate change studies have paid more attention to hydrological impacts (Li et al., 2009; Raje and Mujumdar, 2010; Georgakakos et al., 2012) than to ecological concerns (Chang et al., 1992; Gebre et al., 2014). Studies on the relation of climate change and reservoir management are still rare (Wang et al., 2012; Kerimoglu and Rinke, 2013; Rheinheimer et al., 2015). Some studies have analysed the effect of climate change on reservoirs forcing the hydrodynamic model with historical data where air temperature (Rheinheimer et al., 2015) and sometimes wind speed (Kerimoglu and Rinke, 2013) are modified by a constant quantity. However, all meteorological variables may be affected by climate change and changes are not uniform throughout the year. Wang et al. (2012), instead, used scenarios derived from measured data to explore the effect of variations in climate and hydrology. This approach takes into account climate variability better, but without attempting to make projections of the hydrodynamic behaviour.

Our first objective was to predict the climate change effects on the water temperature and stratification of the reservoir of Bimont, which supplies drinking water to the Provence region and the city of Marseille in France. To account for the effect of climate change we used the latest RCP emission scenarios (van Vuuren et al., 2011) of a regionalised climate model. We used the model EOLE (Salençon, 1997; Salençon and Thébault, 1997) to simulate the hydrodynamic and thermal behaviour of the reservoir of Bimont in the medium term (2036-2065) and in the long term (2066-2095). The paper demonstrates a methodology to predict the effects of climate change on reservoir hydrodynamics that may be applied to other inland water bodies. The second objective was to test whether management actions could reduce the effects of climate change on the hydrodynamic and thermal behaviour of the reservoir of Bimont. To investigate the effect of different management strategies, we considered three management scenarios by varying outlet depth and water level.

\section{METHODS}

\section{Study site}

The reservoir of Bimont lies in Saint Marc Jaumegarde, in the Department of Bouches du Rhône (South of France) (Fig. 1). The Bimont reservoir is part of the water distribution system to the region of Provence

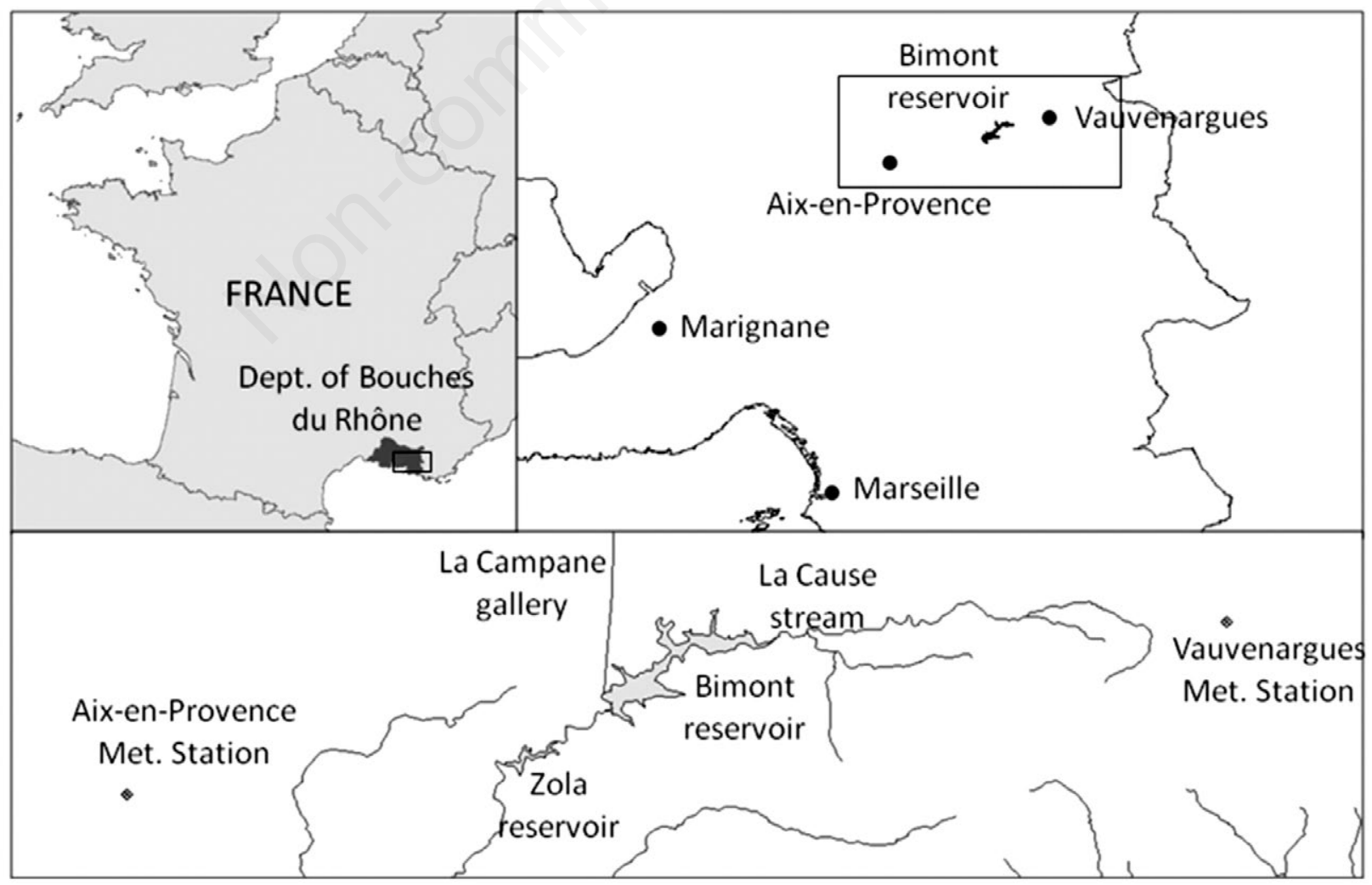

Fig. 1. Study area. 
managed by the Société du Canal de Provence (SCP) and supplies water to the city of Marseille. The reservoir is also used for protection against floods and hydroelectric production.

The arch dam, with a maximum height of $87.5 \mathrm{~m}$ and a length of $355 \mathrm{~m}$, was built in the valley of the stream $\mathrm{La}$ Cause. The reservoir has two main inflows (Fig. 2): The natural tributary, La Cause stream, and an artificial conduct, La Campane gallery. The catchment basin area is $41 \times 10^{6} \mathrm{~m}^{2}$, of which $27 \times 10^{6} \mathrm{~m}^{2}$ correspond to the natural tributary. The artificial inlet structure of La Campane gallery could release water into the reservoir through a $\varnothing$ $1.3 \mathrm{~m}$ outlet at $315 \mathrm{~m}$ asl after passing through a reversible pump-turbine (3-4 in Fig. 2), or it could be diverted through a bypass gate to a chute at $331 \mathrm{~m}$ asl $(2$ in Fig. 2). The dam has two bottom outlets at $288 \mathrm{~m}$ asl (Ø $1.5 \mathrm{~m})$ and $287 \mathrm{~m}$ asl (Ø $0.5 \mathrm{~m})$, and a spillway at $336 \mathrm{~m}$ asl. A small retention dam at the foot of Bimont dam regulates flow withdrawn into the La Cause stream (8 in Fig. 2) and into the Marseille channel (7 in Fig. 2). Most of the outflow is derived through the Marseille channel for irrigation and drinking water.

In normal operation, outflow volumes usually equalled inflow volumes and the water level was maintained approximately constant around $329.5 \mathrm{~m}$ asl, corresponding to a volume of $14 \mathrm{hm}^{3}$. In 1992-2012 the mean flow of the artificial input was $1.5 \mathrm{~m}^{3} \mathrm{~s}^{-1}$ and the mean flow of the main natural tributary was $0.15 \mathrm{~m}^{3} \mathrm{~s}^{-1}$. Under such conditions, the residence time of the reservoir was about 3 months. Being located in an area of karstic geology, the reservoir suffered from losses by infiltration quantified as $0.2-0.3 \mathrm{~m}^{3}$ $\mathrm{s}^{-1}$ (Société du Canal de Provence, 2013).

\section{EOLE model}

We simulated the hydrodynamic behaviour of the reservoir of Bimont with the model EOLE (Salençon,

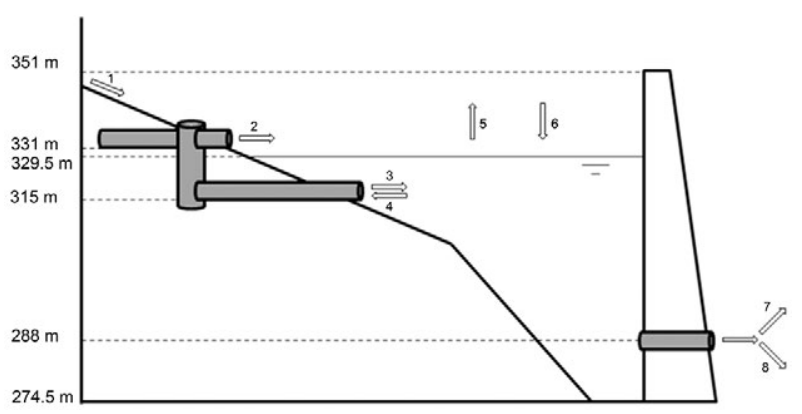

Fig. 2. Flows into and out from the reservoir: 1) natural runoff; 2) artificial inflow derived through the chute; 3 ) artificial turbined inflow; 4) pumped outflow; 5) evaporation; 6) precipitation; 7) outflow derived to the Marseille channel; 8) downstream releases (counter dam).
1997; Salençon and Thébault, 1997). EOLE is a hydrodynamic model (one-dimensional vertical model), based on the representation of individual physical mechanisms, taking into account the bathymetry of the reservoir, surface energy exchanges, and throughflow in the reservoir (rivers, pumping, turbining, residual stream flow, etc.). This model combines an integral mixed-layer model for the epilimnion, a diffusion coefficient model for the hypolimnion and an advective fluxes model for its application to dammed reservoirs. EOLE is described more in detail in the Supplementary material.

\section{Input and validation data}

The French meteorological service (Météo-France) provided hourly meteorological data: air temperature and relative humidity at $2 \mathrm{~m}$ height, wind speed at $10 \mathrm{~m}$, solar radiation, nebulosity, atmospheric pressure and pluviometry. Two meteorological stations exist at a similar distance $(\sim 10 \mathrm{~km})$ from the reservoir: Aix-en-Provence (at an elevation of $173 \mathrm{~m}$ asl, $43^{\circ} 32^{\prime} \mathrm{N} 5^{\circ} 25^{\prime} \mathrm{E}$ ) and Vauvenargues (at an elevation of $565 \mathrm{~m}$ asl, $43^{\circ} 33^{\prime} \mathrm{N} 5^{\circ} 41^{\prime} \mathrm{E}$ ). We used the data from the station of Aix-en-Provence, since it had less missing data and it measured solar radiation. To account for the altitudinal difference between the meteorological station and Bimont reservoir, we applied an adiabatic gradient correction of $-6 \times 10^{-30} \mathrm{C} \mathrm{m}^{-1}$ to air temperature measurements. We used atmospheric pressure measured at Marignane meteorological station $\left(43^{\circ} 26^{\prime} \mathrm{N} 5^{\circ} 13^{\prime} \mathrm{E}\right)$ and nebulosity measured at Marseille meteorological station $\left(43^{\circ} 19^{\prime} \mathrm{N} 5^{\circ} 29^{\prime} \mathrm{E}\right)$, since they were not available at Aix-en-Provence station. We applied an altimetric correction to the atmospheric pressure to account for the elevation effect.

The SCP provided daily inflow and outflow data for 2010-2014 and monthly average flows for 1993-2013. Since outflow measured at the outlets were not precise enough for our study, outflow was calculated as the sum of downstream flow (8 in Fig. 2) and Marseille channel flow (7 in Fig. 2). The inflow of La Cause stream was measured at the gauging station of Gaudinettes $\left(43^{\circ} 33^{\prime} \mathrm{N} 5^{\circ} 34^{\prime} \mathrm{E}\right)$, about $1 \mathrm{~km}$ upstream from the reservoir. The SCP estimated inflow for the rest of the drainage basin from discharge at La Cause basin using Myer formula. We considered infiltration flow as constant and adjusted it around the SCP estimated value to close the hydrologic budget.

Irstea Hydrobiology Unit (HYAX) measured water temperature in the La Cause stream in 2009-2010. We used the data for the La Cause stream to fit a sigmoid air temperature-water temperature regression model (Mohseni et al., 1998):

$$
T_{w}=\mu+\frac{\alpha-\mu}{1+e^{\gamma\left(\beta-T_{a}\right)}}
$$


The fitted coefficients for La Cause were $\alpha=7.35, \beta$ $=19.99, \gamma=-0.18$ and $\mu=23.29$. The fitted regression model had a correlation coefficient of 0.965 and a root mean square error (RMSE) of $1.0^{\circ} \mathrm{C}$. The SCP also provided water temperature measurements for the artificial tributary at the Ryans station, $24 \mathrm{~km}$ upstream from the study site. Equation 1 did not work well for the artificial tributary, since its water was extracted at Gréoux reservoir, downstream from Sainte-Croix reservoir, and it showed a delayed annual water temperature cycle and reduced variability at the scale of days to weeks. So, we used instead the modification proposed by Koch and Grünewald (2010):

$T_{w}=\mu+\frac{\alpha-\mu}{1+e^{\gamma\left[\beta-f\left(T_{a}\right)\right]}}$

where $f\left(T_{a}\right)$ is a moving average

$$
f\left(T_{a}\right)=\frac{1}{n} \sum_{i=0}^{n-1} T_{a}(t-i)
$$

and $n$ is the number of days over which the average was calculated. The fitted coefficients in this case were $\alpha=$ $4.70, \beta=15.28, \gamma=-0.22, \mu=21.34$ and $n=68$. The fitted regression model had a correlation coefficient of 0.988 and a RMSE of $0.7^{\circ} \mathrm{C}$.

We derived the lake bathymetry from the aggregation of two data sources: raster data measured by HYAX using a depth recorder up to the $329 \mathrm{~m}$ asl level; and a 5-m resolution MNT raster obtained from Spot-5 satellite images and provided by the Regional Centre of Geographic Information (CRIGE). Water quality profiles (temperature, dissolved oxygen, conductivity) and Secchi depth were periodically measured in Bimont reservoir since June 2009. Measurements were collected twice a month during the period March 2010 to February 2011, and monthly afterwards.

We extracted surface temperature from infrared thermal images taken every 16 days by the satellites Landsat 5 and Landsat 7 (Simon et al., 2014) for 1999-2013. We excluded images with less than $10 \%$ of non-empty pixels and those for which atmospheric vapour was out of the range of application $\left(0.5-2 \mathrm{~g} \mathrm{~cm}^{-2}\right)$ of the algorithm of Jiménez-Muñoz et al. (2009). We took the median of temperatures in all available pixels in an image as the surface temperature for the water body at a given date. The RMSE of satellite-derived surface temperatures was about $1-2^{\circ} \mathrm{C}$ (Simon et al., 2014).

\section{Limitations of the input data}

In this section, we analyse uncertainties in the input data that can affect the simulation results. Meteorological conditions above a freshwater body can differ from those measured at the nearest meteorological station (Benyahya et al., 2012), often located at several kilometres. To assess meteorological variability in the study area, we compared meteorological measurements at the stations of Aix-enProvence and Vauvenargues, finding significant differences between them. Average wind speed at Vauvenargues was $0.60 \mathrm{~m} / \mathrm{s}$ higher than at Aix-en-Provence. The average difference of $2.3^{\circ} \mathrm{C}$ in air temperature could be attributed to the difference in altitude between both stations considering a usual altitudinal gradient of $-6^{\circ} \mathrm{C} \mathrm{km}^{-1}$. Additionally, the data of the meteorological reanalysis SAFRAN (Quintana-Seguí et al., 2008; Vidal et al., 2010) with a spatial resolution of $8 \mathrm{~km}$ demonstrated the existence of spatial variability in the area surrounding the reservoir of Bimont and both meteorological stations. Although too fine to be resolved by the SAFRAN reanalysis, other geographical features may influence the local climate at Bimont reservoir: to the Southwest of the reservoir of Bimont the Sainte Victoire range, with elevations of 900$1000 \mathrm{~m}$, extends in an E-W direction for about $8 \mathrm{~km}$; and to the North and West of the reservoir there is a plateau with elevations of 400-500 m, so that the reservoir of Bimont is in a sort of cuvette.

The sensitivity analysis (see below and Supplementary material) showed that the model was most sensible to air temperature, solar radiation and wind speed, and slightly sensitive to the temperature of the inflows. So, we applied calibration coefficients to the meteorological forcing to account for differences in microclimatic conditions and shading. We also applied an additive coefficient to the temperature of the inflows to account for a possible systematic bias in the measurement of the temperature of the artificial tributary, measured at $24 \mathrm{~km}$ of the reservoir, and in the estimation of the temperature of the natural tributary.

$$
\begin{aligned}
& T_{a, \text { lake }}=T_{a}+\delta+C_{T a} \\
& H S_{\text {lake }}=C_{H S} * H S \quad C_{H S} \in[0,1] \\
& W_{\text {lake }}=C_{1, W}+C_{2, W} W \\
& T_{n i, \text { lake }}=T_{n i}+C_{T n i} \\
& T_{\text {ai,lake }}=T_{a i}+C_{T a i}
\end{aligned}
$$

The variables $T_{a}, H S, W, T_{n i}$ and $T_{\mathrm{ai}}$ are, respectively, measured air temperature, solar radiation, wind speed, water temperature of the natural inflow and water temperature of the artificial inflow. $T_{\text {a,lake }}, H S_{\text {lake }}, W_{\text {lake }}, T_{\text {ni,lake }}$ and $T_{a i, \text { lake }}$ are, respectively, air temperature, solar radiation, wind speed, temperature of the natural inflow and temperature of the artificial inflow applied at the lake. $C_{T a}$, $C_{H S}, C_{1, W}, C_{2, W}, C_{T n i}$ and $C_{T a i}$ are correction coefficients and $\delta=-0.94^{\circ} \mathrm{C}$ is the adiabatic correction. 
Hydrological input data showed several problems related to missing data, uncertainty of flow data and infiltration losses. The flow data contained some short periods with missing data, sometimes for more than one variable at a time. We estimated missing data through a hydrologic budget when possible and by interpolation otherwise. When more than one flow variable had missing data the distribution of flow between the different variables was highly uncertain. In addition, the volume of the infiltration losses and the discharge of the natural catchment area discharge were more uncertain than the other inflows and outflows because of the difficulty in estimating them. We estimated infiltration losses as $0.29 \mathrm{~m}^{3} \mathrm{~s}^{-1}$, about $20 \%$ of mean throughflow. This estimation is coherent with the estimation of the SCP of $0.2-0.3 \mathrm{~m}^{3} \mathrm{~s}^{-1}$ through a hydrologic balance. However, the accuracy of the estimation of infiltration losses depends on the accuracy of the estimation of the flow from the natural catchment area. Finally, the infiltration depth was unknown. Studies by the SCP indicate that infiltration may take place at $310 \mathrm{~m}$ asl (Société du Canal de Provence, 2013). But a preliminary study of Bimont by Dutordoir (2010) with Dyresm indicated an improvement of the modelling performance (especially in the bottom layers) when water infiltrated at the bottom of the reservoir. This result confirmed the disparate nature of this outflow, gathering infiltration, dam water leaks and flow uncertainties. As Dutordoir (2010), we located the infiltration near the bottom, at $285.8 \mathrm{~m}$ asl.

\section{Sensitivity analysis and calibration}

We identified influential parameters through a local sensitivity analysis, where we varied the value of individual parameters in a plausible range while maintaining the value of the other parameters constant. The Tab. S1 shows the values of the calibration parameters. We calibrated the model using data for 2010-2011 and we validated it for January 2012August 2014. See the Supplementary material for details on the sensitivity analysis and calibration. Besides, we validated the simulated surface temperatures by comparing simulation results for 1993-2013 to satellite measurements.

\section{Management and climate scenarios}

To assess the effects of climate change under different management strategies, we created three compound scenarios:

- The current management strategy of maintaining a constant water level at $329.5 \mathrm{~m}$ asl with higher flows in summer than in winter.

- Elevating the water level to $340 \mathrm{~m}$ asl, a possibility under study by the SCP after the planned strengthening works at Bimont reservoir.

- Using a surface outlet instead of a bottom one and a water level at $340 \mathrm{~m}$ asl.
In all three cases, we assumed the outflows to follow the present seasonal pattern, modelled through a sinusoidal function. We estimated inflows from La Cause stream using the hydrological model GR4J (Perrin et al., 2003) and we adjusted artificial inflows to keep a constant water level.

We used regionalized projections from project CORDEX (Giorgi et al., 2009) issued by the downscaling model RCA4 (Kupiainen et al., 2011; Samuelsson et al., 2011) applied to the projections of the climate model CNRM-CERFACS-CNRM-CM5 (Voldoire et al., 2013). We downloaded the projections for the two climate scenarios RCP4.5 and RCP8.5, which represent an intermediate emissions scenario and a high emissions scenario respectively (van Vuuren et al., 2011), from the Earth System Grid Federation (ESGF) Portal (http://esgf.llnl.gov/). Regionalized output had a spatial resolution of $0.11^{\circ}$, approximately $12.5 \mathrm{~km}$, and daily periodicity. We extracted the regionalized climate model (RCM) projection data for two different 30-year periods: 2036-2065 for a mediumterm horizon, and 2066-2095 for a long term horizon. To limit the effect of initial conditions we initialized scenario simulations two years before the study period for 329.5 $\mathrm{m}$ water level simulations and three years before the study period for $340 \mathrm{~m}$ water level simulations. We used a longer initialization time for higher levels because of the longer residence time. We corrected the projections data using the quantile-quantile method (Boé et al., 2007).

We estimated inflow temperatures using equations 13. Although water-air temperature regressions have often been used to predict climate change effects on freshwater temperatures (Mohseni et al., 1999; Rübbelke and Vögele, 2011), Arismendi et al. (2014) cautioned against their use to predict temperatures outside the calibration period. To test the validity of using regressions, we compared the regression predictions to those of the processbased model CALNAT (Gosse et al., 2008). Both CALNAT and the regression models had a similar good performance when applied on calibration data, and predicted similar temperatures when applied on climate projections data. These results are coherent with those obtained by Bustillo et al. (2014). In addition, inflow water temperatures depend on climatic factors as well as on human influences such as management and urbanization. The latter are difficult to take into account in the models. So, we used sigmoid regressions for parsimony reasons following Bustillo et al. (2014).

We compared the results obtained for the different management and climate scenarios to the results of historical simulations for the 21-year period 1993-2013. We selected this period because it was the longest one with hourly meteorological data available for all variables. We ran an additional simulation (P_Ref_RCM scenario) for 1993-2013 using RCM data and maintaining a constant water level to 
assess the effect of possible biases in simulated meteorological and inflow input data. For this simulation we used two types of RCM data, the hindcasts for 1993-2005 and the projection for the RCP 4.5 scenario for 2006-2013.

We tested the differences between the reference simulation and the different scenarios in several variables using the Mann-Whitney test. We did similarly for the comparison between the Ref simulation and the P_Ref_RCM simulation. We tested the differences between management scenarios under the same meteorological forcing with a paired Mann-Whitney test. The Tab. 1 summarizes the scenarios used.

\section{Metrics used}

We assessed the effect of climate change and management practices with different water temperature and stratification metrics. The water temperature metrics were mean annual epilimnion temperature, maximum annual epilimnion temperature, minimum annual epilimnion temperature, mean annual hypolimnion temperature, maximum annual hypolimnion temperature and minimum annual hypolimnion temperature. We calculated epilimnion temperature as the average temperature above the thermocline in the stratification period and the average temperature of the water body during the mixing period. Similarly, we calculated hypolimnion temperature as the average temperature below the thermocline in the stratification period and the average temperature of the water body during the mixing period.

The stratification metrics were the thermocline depth, the date of start of the stratification period, the date of end of the stratification period and the length of the stratification period. The thermocline depth was calculated by EOLE as one of the output variables following Patterson et al. (1984). We extracted it on different days of the year $(120,150,180,210$ and 240) to analyse the evolution of stratification during the year. We defined the stratification period as the longest period without mixing where the difference between epilimnion temperature and hypolimnion temperature was at least $0.5^{\circ} \mathrm{C}$.

In addition, we also calculated mean annual evaporation to assess the variation in evaporative losses in different scenarios.

\section{RESULTS}

\section{Hydrodynamic behaviour of the reservoir}

Bimont reservoir is a monomictic reservoir, stratified between April and September in three stable layers (Fig. 3): An epilimnion, a wide metalimnion and a small hypolimnion. The epilimnion had a depth of 4-5 $\mathrm{m}$ and a two-meter deep diurnal surface mixed layer was often observed during the stratification period. The position of the bottom outlet (13.5 $\mathrm{m}$ above the bottom) hampered the exchanges of the bottom layers with the upper ones and created a wide metalimnion. This layer was relatively active due to the advective flows: it received water inlets when their densities matched and provided water to the bottom outlet. This was most clearly seen in 2010, when more profiles were available (Fig. 3).

Tab. 1. Characteristics of the scenarios used.

\begin{tabular}{|c|c|c|c|c|c|}
\hline Scenario name & $\begin{array}{l}\text { Water } \\
\text { level } \\
\text { (m asl) }\end{array}$ & $\begin{array}{c}\text { Outlet } \\
\text { level } \\
\text { (m asl) }\end{array}$ & Climate scenario & Period & Code \\
\hline Reference & $\sim 329.5$ & 288 & Historical measurements & $1993-2013$ & Ref \\
\hline RCM Reference & 329.5 & 288 & Historical simulation (1993-2005) + RCP4.5 (2006-2013) & $1993-2013$ & P_Ref_RCM \\
\hline \multirow[t]{2}{*}{ Present management $(\mathrm{P})$} & \multirow[t]{2}{*}{329.5} & \multirow[t]{2}{*}{288} & $\mathrm{RCP} 4.5$ & $\begin{array}{l}2036-2065 \\
2066-2095\end{array}$ & $\begin{array}{l}\text { P_m_rcp45 } \\
\text { P_1_rcp45 }\end{array}$ \\
\hline & & & $\mathrm{RCP} 8.5$ & $\begin{array}{l}2036-2065 \\
2066-2095\end{array}$ & $\begin{array}{l}\text { P_m_rcp85 } \\
\text { P_1_rcp85 }\end{array}$ \\
\hline \multirow[t]{3}{*}{ Elevated water level (E) } & \multirow[t]{3}{*}{340} & \multirow[t]{3}{*}{288} & Historical simulation $(1993-2005)+\mathrm{RCP} 4.5(2006-2013)$ & 1993-2013 & E_Ref_RCM \\
\hline & & & $\mathrm{RCP} 4.5$ & $\begin{array}{l}2036-2065 \\
2066-2095\end{array}$ & $\begin{array}{l}\text { E_m_rcp45 } \\
\text { E_1_rcp45 }\end{array}$ \\
\hline & & & $\mathrm{RCP} 8.5$ & $\begin{array}{l}2036-2065 \\
2066-2095\end{array}$ & $\begin{array}{l}\text { E_m_rcp85 } \\
\text { E_1_rcp85 }\end{array}$ \\
\hline \multirow[t]{3}{*}{ Lake-like (surface outlet) (L) } & \multirow[t]{3}{*}{340} & \multirow[t]{3}{*}{340} & Historical simulation (1993-2005) + RCP4.5 (2006-2013) & $1993-2013$ & L_Ref_RCM \\
\hline & & & $\mathrm{RCP} 4.5$ & $\begin{array}{l}2036-2065 \\
2066-2095\end{array}$ & $\begin{array}{l}\text { L_m_rcp45 } \\
\text { L_1_rcp45 }\end{array}$ \\
\hline & & & RCP8.5 & $\begin{array}{l}2036-2065 \\
2066-2095\end{array}$ & $\begin{array}{l}\text { L_m_rcp85 } \\
\text { L_1_rcp85 }\end{array}$ \\
\hline
\end{tabular}



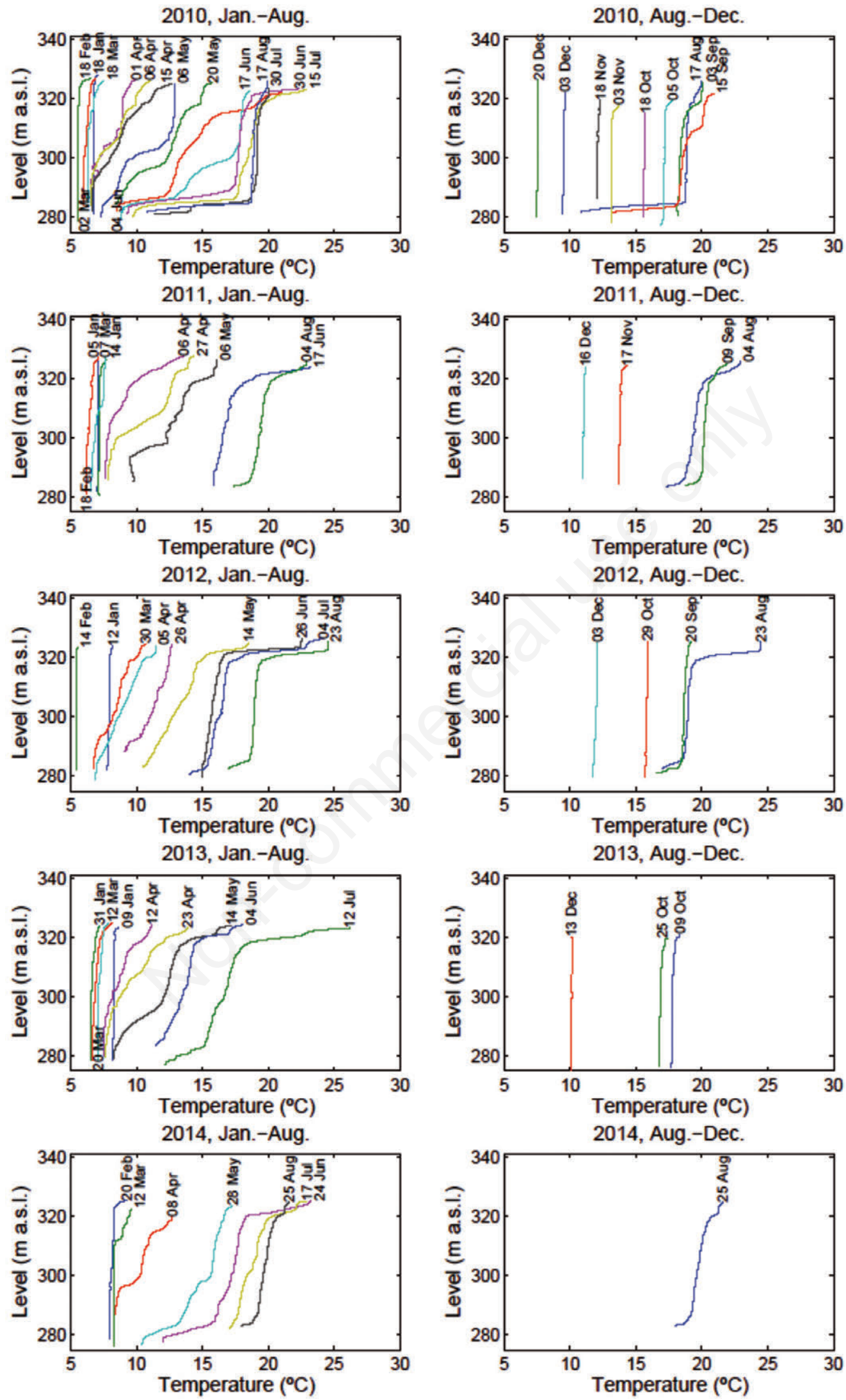

Fig. 3. Temperature profiles at the reservoir of Bimont between January 2010 and August 2014. 


\section{Evaluation of model performance}

The quality of the simulations of the thermal behaviour of Bimont reservoir was acceptable (Fig. 4A): The RMSE was $1.32^{\circ} \mathrm{C}$ for the calibration period and $1.08^{\circ} \mathrm{C}$ for the validation period; and mean bias was $-0.38^{\circ} \mathrm{C}$ in the calibration period and $-0.11^{\circ} \mathrm{C}$ in the validation period. The simulation performance was better for the epilimnion temperature $\left(\mathrm{RMSE}\right.$ of $1.00^{\circ} \mathrm{C}$ ) than for the hypolimnion temperature (RMSE of $2.76^{\circ} \mathrm{C}$ ). Epilimnion temperature tended to be overestimated, and hypolimnion temperature underestimated and a seasonal error pattern appeared (check Figs. S2 and S3 and the Supplementary material for more information).

Model performance depends on the characteristics of the calibration period (Van Straten and Keesman, 1991; Andréassian et al., 2012). Long term satellite data showed the long-term stability of the simulation performance (Fig. 4B). Satellite surface temperature measurements were available for only 132 images, about one third of all images taken in 1999-2013. The RMSE of the simulation respect to satellite measurements was $1.54^{\circ} \mathrm{C}$, mean bias was $-0.69^{\circ} \mathrm{C}$ and the correlation coefficient was 0.9715 .

\section{Changes in meteorological variables under different climate scenarios}

Fig. 5 compares the meteorological variables predicted by the 6 climate scenarios. The air temperature was the meteorological parameter most sensitive to climate scenarios. The average air temperature increased between 1.0 and $1.4^{\circ} \mathrm{C}$ in the medium-term scenario and between 1.3 and $2.9^{\circ} \mathrm{C}$ in the long-term one. The RCM predicted especially important temperature increases in the long-term RCP 8.5 scenario, up to $\sim 3-4^{\circ} \mathrm{C}$ in autumn and winter and $2.8-2.9^{\circ} \mathrm{C}$ in July and August. Solar radiation measurements showed a statistically significant increasing trend of $0.49 \mathrm{~W} \mathrm{~m}^{-2}$ $\mathrm{yr}^{-1}$, stabilizing at an annual average of $\sim 135 \mathrm{~W} \mathrm{~m}^{-2} \mathrm{~d}^{-1}$ at the end of the 1993-2013 period. The climate model slightly overestimated solar radiation by $10-20 \mathrm{~W} \mathrm{~m}^{-2}$ from April to August, 5-10\% of total radiation, in the same period. This is probably due to an underestimation of cloudiness over land in the Northern Hemisphere because of errors in the convective and cloud parameterizations of the CNRM-CM5.1 model (Voldoire et al., 2013) from which regionalized data was derived. Contrasting to the increasing trend in the solar radiation measurements, the RCM simulations showed no differences between the reference, medium term or long term scenarios.

There were also differences in the annual cycle of relative humidity respect to reference conditions. The RCM predicted lower relative humidity in the summer and autumn and a higher humidity between February and April than meteorological measurements for 1993-2013. The magnitude of the differences was of $5 \%$ as a maximum, occurring in August. A similar pattern persisted in future climate scenarios.

Simulated wind speed was close to measurements in 1993-2013. The climate model did not predict future variations in wind speed. Average precipitation varied little in the climate projections, between $551 \mathrm{~mm} \mathrm{yr}^{-1}$ and $646 \mathrm{~mm}$ $\mathrm{yr}^{-1}$, compared to the $600 \mathrm{~mm} \mathrm{yr}^{-1}$ of the reference period, and followed a similar annual cycle. Also, there were no
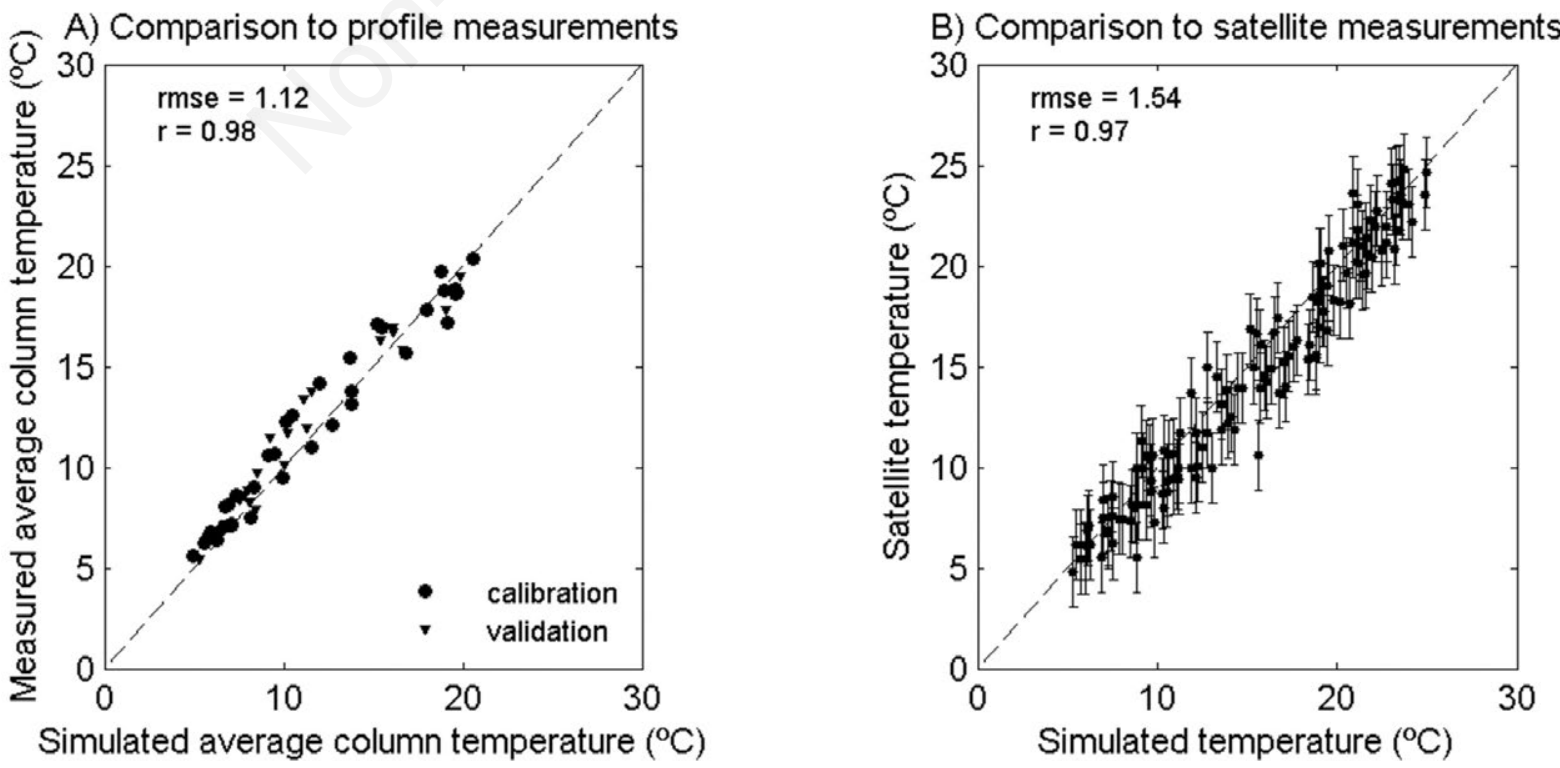

Fig. 4. Measurements against simulated water temperature in the period 1999-2013. Error bars correspond to a standard error of $1.753^{\circ} \mathrm{C}$ for satellite measurements as found by Simon et al. (2014). 
clear trends in precipitation. In the long term, precipitation was lower than in the reference period under the RCP 8.5 scenario, but higher under the RCP 4.5 scenario. Finally, there were no important differences in atmospheric pressure between the reference period and climate projections.

In summary, the meteorological variables predicted by climate projections under the RCP 4.5 scenario in the medium and long term were very similar among themselves and to the medium-term projection under RCP 8.5 scenario. Only the long-term RCP 8.5 scenario differed as it was significantly warmer than the other scenarios. According to the RCM simulations, the effect of climate change in the meteorological variables will mainly be an increase in air temperature, driven by increasing atmospheric longwave radiation.

\section{Effect of climate change on simulated inflow temperatures}

As a result of increased air temperatures, inflow temperatures are expected to increase (Fig. 6). For the natural inflow, the predicted increase is of $0.4-0.6^{\circ} \mathrm{C}$ in the medium term and $0.6-1.4^{\circ} \mathrm{C}$ in the long-term respect to the reference period. For the artificial inflow, the predicted increase is more important, of $0.6-0.9^{\circ} \mathrm{C}$ in the medium term and $0.8-1.9^{\circ} \mathrm{C}$ in the long term.

\section{Comparison of simulations for the reference period using measured and synthetic data}

To assess the limitations of using synthetic data to study the hydrodynamic behaviour of the reservoir of Bimont, we compared the simulations made using measurements and RCM output for the reference period. In the Ref scenario flow data was much more variable in time than the almost sinusoidal flow function used for the P_Ref_RCM scenario. Small differences were also observed in the annual cycle between meteorological measurements and RCM output for the reference period. These differences represent a source of error that may appear in simulations of future scenarios. According to the MannWhitney test, there were statistically significant differences in the metrics calculated under both scenarios for mean annual epilimnion temperature, maximum annual epilimnion temperature, depth of the thermocline on days 120, 210 and 240, and mean annual evaporation (Tab. 2).
A) Atmospheric pressure

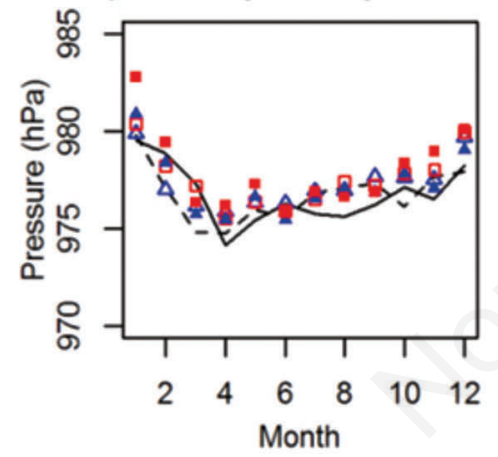

D) Solar radiation

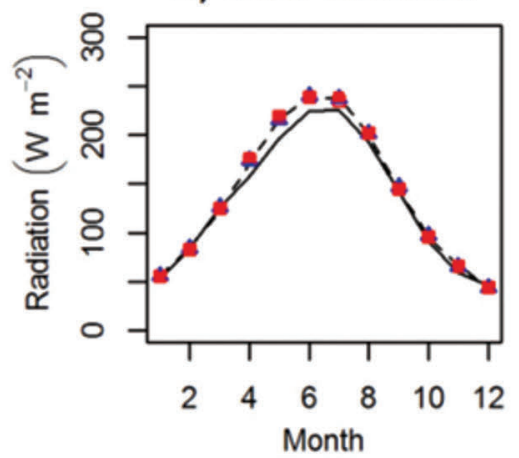

B) Air temperature

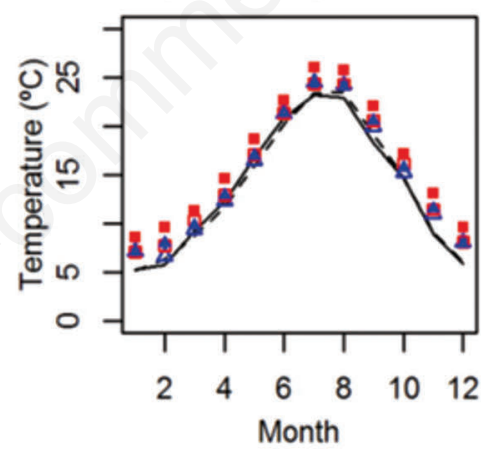

E) Wind speed

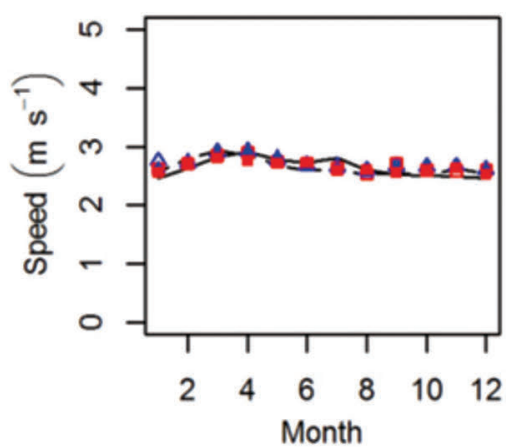

C) Relative humidity

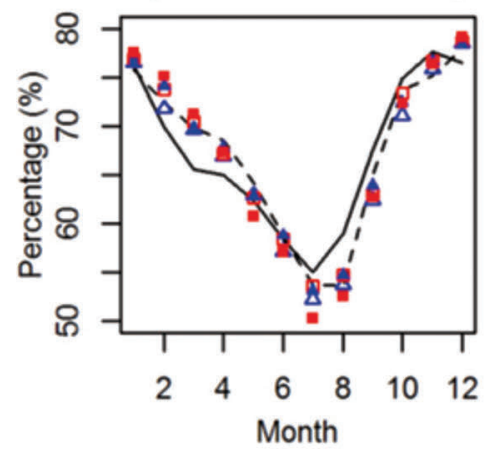

F) Daily precipitation

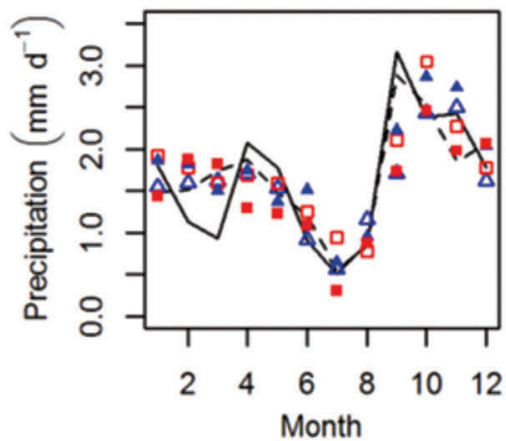

Fig. 5. Mean monthly value of meteorological variables: measures (continuous line) and RCM output (discontinuous line) in the reference period, and RCM output for the climate scenarios RCP 4.5 (blue triangles) and RCP 8.5 (red squares) in the medium (empty symbol) and long (filled symbol) term. 

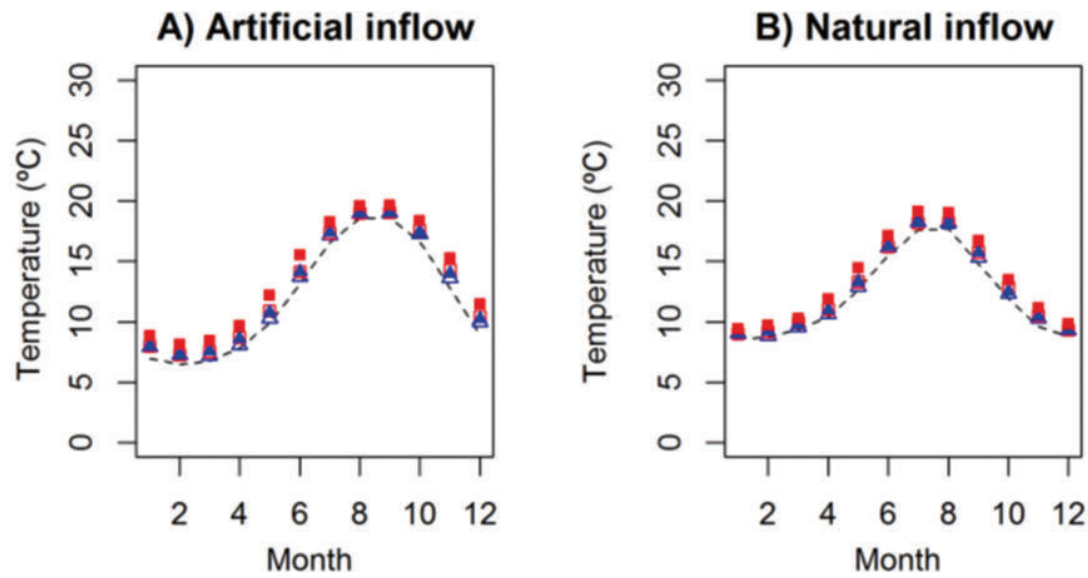

Fig. 6. Mean monthly value of simulated artificial (A) and natural (B) inflow temperatures: RCM output for the reference period (discontinuous line), and for the climate scenarios RCP 4.5 (blue triangles) and RCP 8.5 (red squares) in the medium (empty symbols) and long (filled symbols) term.

Tab. 2. Median values of different metrics under the Ref and P_Ref_RCM scenarios, $1^{\text {st }}$ and $3^{\text {rd }}$ quartiles (in brackets) and difference of means and medians between both scenarios.

\begin{tabular}{|c|c|c|c|c|}
\hline Metric & $\begin{array}{c}\text { Ref } \\
\text { scenario }\end{array}$ & $\begin{array}{l}\text { P_Ref_RCM } \\
\text { scenario }\end{array}$ & $\begin{array}{l}\text { Difference of means } \\
\text { (P_Ref_RCM - Ref) }\end{array}$ & $\begin{array}{l}\text { Difference of medians } \\
\text { (P_Ref_RCM - Ref) }\end{array}$ \\
\hline Mean annual epilimnion temperature $\left({ }^{\circ} \mathrm{C}\right)$ & $\begin{array}{c}14.15 \\
(13.96-14.44)\end{array}$ & $\begin{array}{c}13.84 \\
(13.68-14.18)\end{array}$ & -0.31 & $-0.30 *$ \\
\hline Max. annual epilimnion temperature $\left({ }^{\circ} \mathrm{C}\right)$ & $\begin{array}{c}22.09 \\
(21.68-22.63)\end{array}$ & $\begin{array}{c}21.86 \\
(21.45-21.99)\end{array}$ & -0.46 & $-0.23 *$ \\
\hline Min. annual epilimnion temperature $\left({ }^{\circ} \mathrm{C}\right)$ & $\begin{array}{c}5.86 \\
(5.42-6.67)\end{array}$ & $\begin{array}{c}5.74 \\
(5.01-6.24)\end{array}$ & -0.38 & -0.12 \\
\hline Mean annual hypolimnion temperature $\left({ }^{\circ} \mathrm{C}\right)$ & $\begin{array}{c}9.71 \\
(9.31-9.97)\end{array}$ & $\begin{array}{c}9.80 \\
(9.42-10.11)\end{array}$ & 0.06 & 0.09 \\
\hline Max. annual hypolimnion temperature $\left({ }^{\circ} \mathrm{C}\right)$ & $\begin{array}{c}18.15 \\
(15.16-18.49)\end{array}$ & $\begin{array}{c}17.80 \\
(15.31-19.13)\end{array}$ & 0.28 & -0.35 \\
\hline Min. annual hypolimnion temperature $\left({ }^{\circ} \mathrm{C}\right)$ & $\begin{array}{c}5.79 \\
(5.34-6.58)\end{array}$ & $\begin{array}{c}5.70 \\
(4.92-6.20)\end{array}$ & -0.24 & -0.09 \\
\hline Start of the stratification period (day of the year) & $\begin{array}{c}58 \\
(54-69)\end{array}$ & $\begin{array}{c}65 \\
(52-75)\end{array}$ & 4 & 7 \\
\hline End of the stratification period (day of the year) & $\begin{array}{c}288 \\
(281-321)\end{array}$ & $\begin{array}{c}292 \\
(287-313)\end{array}$ & 0 & 4 \\
\hline Length of the stratification period (days) & $\begin{array}{c}235 \\
(222-264)\end{array}$ & $\begin{array}{c}238 \\
(221-262)\end{array}$ & -4 & 3 \\
\hline Thermocline depth on day $120(\mathrm{~m})$ & $\begin{array}{c}15.8 \\
(13.5-19.9)\end{array}$ & $\begin{array}{c}19.3 \\
(17.5-22.7)\end{array}$ & 3.4 & $3.5^{*}$ \\
\hline Thermocline depth on day $150(\mathrm{~m})$ & $\begin{array}{c}17.0 \\
(15.8-18.4)\end{array}$ & $\begin{array}{c}17.8 \\
(16.9-20.3)\end{array}$ & 0.9 & 0.8 \\
\hline Thermocline depth on day $180(\mathrm{~m})$ & $\begin{array}{c}20.1 \\
(19.0-22.6)\end{array}$ & $\begin{array}{c}21.8 \\
(20.8-22.5)\end{array}$ & 0.5 & 1.7 \\
\hline Thermocline depth on day $210(\mathrm{~m})$ & $\begin{array}{c}27.8 \\
(24.8-29.4)\end{array}$ & $\begin{array}{c}29.0 \\
(28.4 .2-30.7)\end{array}$ & 1.6 & $1.2 *$ \\
\hline Thermocline depth on day 240 (m) & $\begin{array}{c}35.1 \\
(30.9-37.6)\end{array}$ & $\begin{array}{c}38.8 \\
(37.3-42.0)\end{array}$ & 4.7 & $3.7^{*}$ \\
\hline Evaporation $\left(\mathrm{m}^{3} \cdot \mathrm{s}^{-1}\right)$ & $\begin{array}{c}0.0220 \\
(0.0203-0.0237)\end{array}$ & $\begin{array}{c}0.0235 \\
(0.0229-0.0240)\end{array}$ & 0.0016 & $0.0015^{*}$ \\
\hline
\end{tabular}

*Statistically significant differences of medians for $\alpha=0.05$ according to the Mann-Whitney test. 
Average and maximum epilimnion temperatures calculated under the P_Ref_RCM scenario were about $0.3^{\circ} \mathrm{C}$ cooler in average than under the Ref scenario. The simulated epilimnion under the P_Ref_RCM scenario was somewhat deeper than under the Ref scenario at the beginning (day 120) and end (days 210 and 240) of the stratification period.

Although temperatures were slightly higher in the Ref simulation, evaporation was $\sim 7 \%$ higher in the $\mathrm{P}$ Ref RCM simulation because of the differences in wind speed and relative humidity seasonality. So using synthetic data did not create a significant bias, except for thermocline depth.

\section{Thermodynamic behaviour of the reservoir of Bimont under different climate scenarios}

In this section we describe the effect of the climate scenarios RCP 4.5 and RCP 8.5 under the present management strategy (mean water level at $329.5 \mathrm{~m}$ asl and bottom outlet). We present the results for the corresponding scenarios P_m_rcp45, P_m_rcp85, P_1_rcp45 and P_1_rcp85 in the Figs. 7-9. In the next section we describe the differences between the three management types under both climate scenarios.

In future scenarios water temperatures in the epilimnion and hypolimnion show a warming trend more important under the RCP 8.5 scenario (Fig. 7). The increase in mean epilimnion temperatures is $0.4-0.8^{\circ} \mathrm{C}$ in the medium term and between $0.7^{\circ} \mathrm{C}$ and $1.9^{\circ} \mathrm{C}$ in the long term, depending on the climate scenario. Temperature increased most in the RCP 8.5 scenario. Maximum annual epilimnion temperature increased only in the long-term RCP 8.5 scenario, when maximum epilimnion temperature was $1.0^{\circ} \mathrm{C}$ warmer than under the reference conditions. In contrast, minimum annual temperatures in the epilimnion increased more than either mean or maximum temperatures. Minimum epilimnion temperatures increased between $0.8^{\circ} \mathrm{C}$ and $1.1^{\circ} \mathrm{C}$ in the medium term and between $0.9^{\circ} \mathrm{C}$ and $2.4^{\circ} \mathrm{C}$ in the long-term.

Mean annual hypolimnion temperatures were higher in all scenarios than present conditions due to winter warming (by $0.8-1.1^{\circ} \mathrm{C}$ in the medium term). Hypolimnion temperatures remained quite stable between the middle and the end of the century under the RCP 4.5 scenario $\left(+1.0^{\circ} \mathrm{C}\right.$ respect to reference conditions), but they increased by still another degree under the RCP 8.5 scenario $\left(+2.2^{\circ} \mathrm{C}\right.$ respect to reference conditions). Maximum annual hypolimnion temperatures were warmer than reference conditions by $1.3^{\circ} \mathrm{C}$ in the medium term and by $1.0-2.3^{\circ} \mathrm{C}$ in the long term. Minimum annual hypolimnion temperature increased by between 0.8 and $1.1^{\circ} \mathrm{C}$ in the medium term and between 0.9 and $1.9^{\circ} \mathrm{C}$ in the long-term.

Under the present management strategy, there were no statistically significant differences between the reference period and future scenarios regarding the length, start or end of the stratification period (Fig. 8). The thermocline depth tended to increase in future scenarios (Fig. 8), with the difference between the reference scenario and medium term scenarios remaining quite stable as the year advanced. On the day of the year 120 , the thermocline was significantly deeper for the $\mathrm{P} \_\mathrm{m} \_$rcp 85 scenario $(+3 \mathrm{~m})$ and for the P_1_rcp45 (+4 m). On the day of the year 150 and 180 , the thermocline was about 2-3 $\mathrm{m}$ deeper than in reference conditions. On day 210, the thermocline was 2 $\mathrm{m}$ deeper under the RCP 8.5 scenarios. Finally, on day 240 , the average differences between the reference period and future scenarios attained 3-5 m for all scenarios. These differences, however, are of the same order of magnitude as the difference in thermocline depth between the Ref and P_Ref_RCM scenarios.

Mean annual evaporation augmented in future scenarios (Fig. 9) due to lower air humidity. Evaporation increased by $0.003-0.004 \mathrm{~m}^{3} \mathrm{~s}^{-1}$, but varied somewhat from period to period. The highest evaporation, at a median rate of 0.0257 $\mathrm{m}^{3} \mathrm{~s}^{-1}$, occurred for the long-term RCP 8.5 scenario. Under the RCP 4.5 scenario, there were no statistically significant differences between the medium and the long term. But under the RCP 8.5 scenario the median of mean annual evaporation increased with statistical significance by 0.001 $\mathrm{m}^{3} \mathrm{~s}^{-1}$ between the medium- and the long-term.

\section{Effect of different management options}

According to the simulations, the different management options may alter significantly the thermodynamic behaviour of the reservoir (Figs. 7-9). Elevating the water level at the reservoir of Bimont reduced annual mean and maximum epilimnion temperatures and modified the development of the thermocline. Under the E scenarios ( $340 \mathrm{~m}$ water level and bottom outlet), the mean epilimnion temperature was reduced by $\sim 0.3^{\circ} \mathrm{C}$, and the maximum epilimnion temperature was reduced by $\sim 1.0-1.2^{\circ} \mathrm{C}$. At the beginning of the stratification period the thermocline under the $\mathrm{E}$ scenarios was about $2 \mathrm{~m}$ shallower than under the P scenarios, on day 210 the thermocline depth was approximately the same in both types of scenarios, and at the end of the stratification period the thermocline was deeper with higher water levels.

These modifications were more important if a surface outlet was also used (L scenarios). Then the mean epilimnion temperature was reduced by $\sim 0.9^{\circ} \mathrm{C}$ and the maximum epilimnion temperature was reduced by $\sim 1.7-1.9^{\circ} \mathrm{C}$. In addition, the thermocline became several meters shallower, the mean hypolimnion temperature decreased by $\sim 2^{\circ} \mathrm{C}$ and the maximum hypolimnion temperature decreased by $\sim 7^{\circ} \mathrm{C}$, indicating a sharper transition between the epilimnion and the hypolimnion. The greater stability of the stratification also caused a delay of the end of the stratification season of about 50 days. 


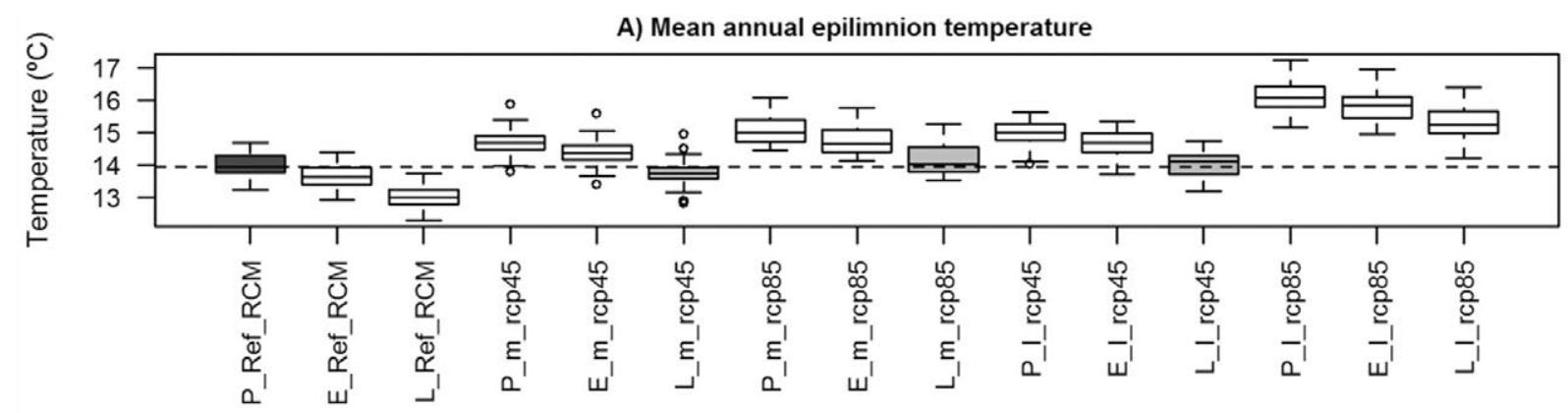

B) Maximum annual epilimnion temperature

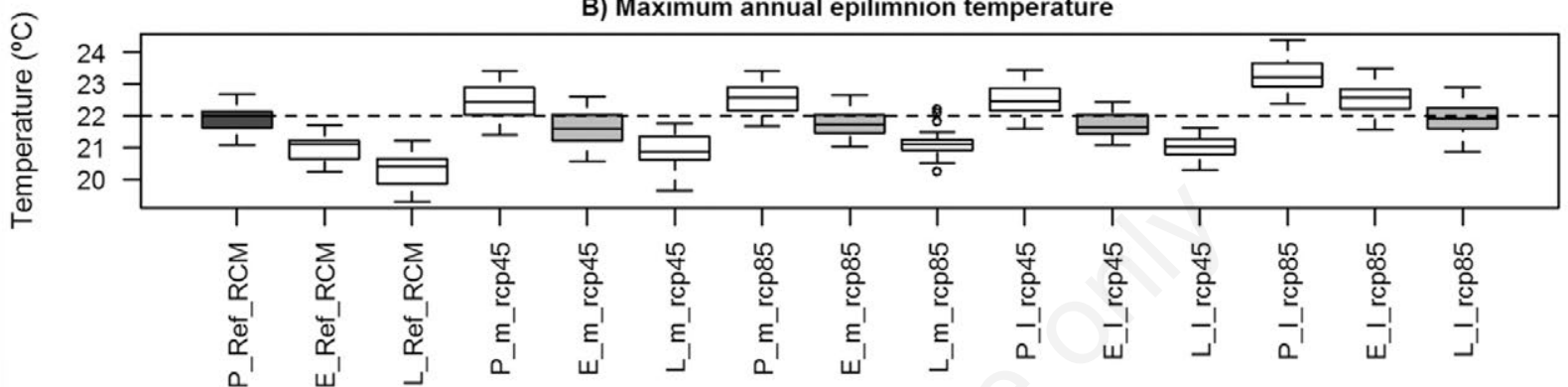

C) Minimum annual epilimnion temperature

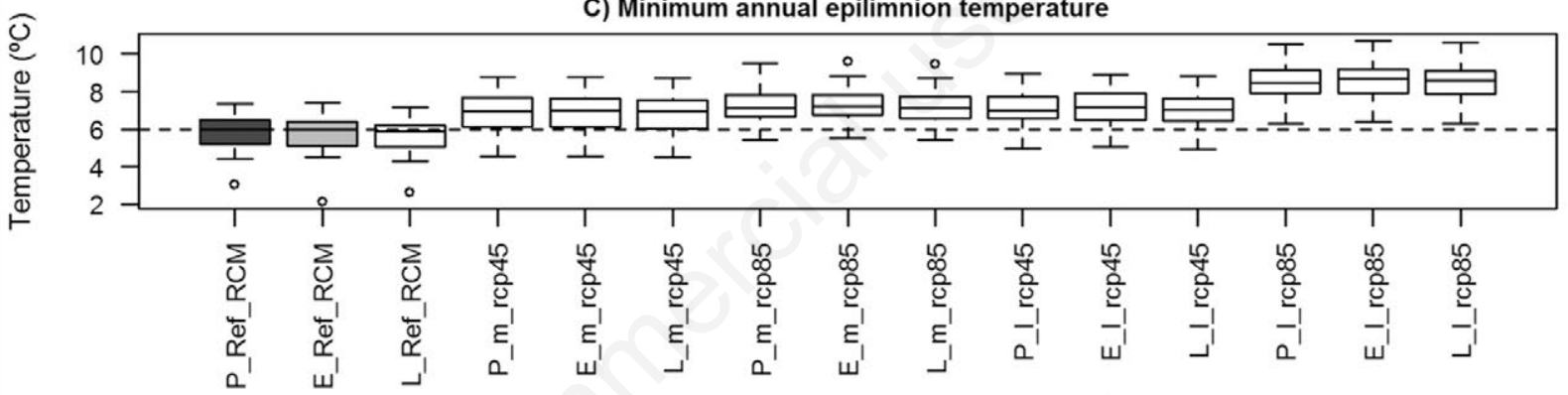

D) Mean annual hypolimnion temperature

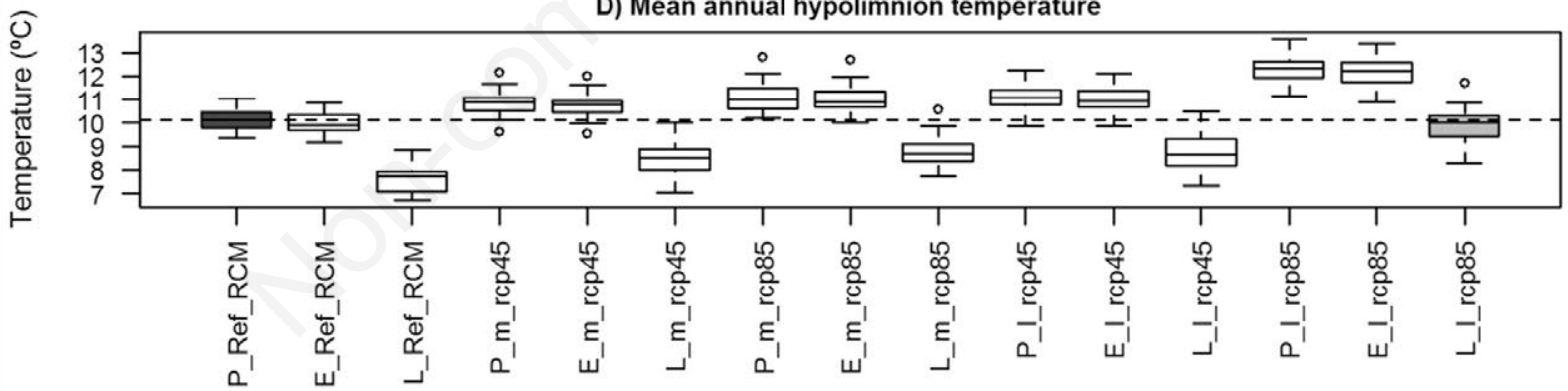

E) Maximum annual hypolimnion temperature

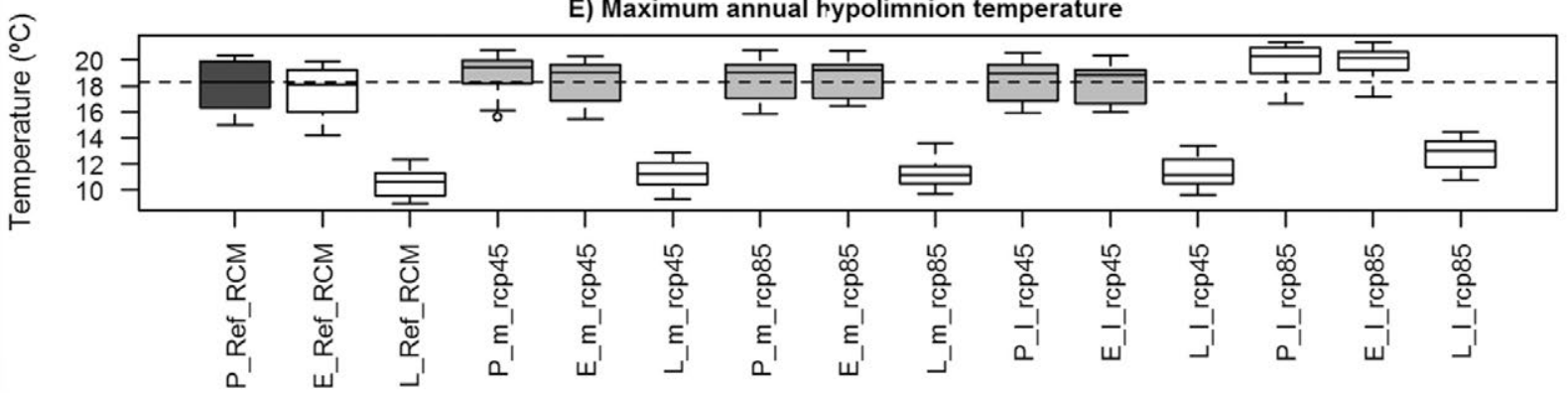

Fig. 7. Water temperature metrics under different scenarios. The scenarios names are composed of three elements (see Tab. 1 for more details): type of hydraulic management (present water level (P), elevated water level (E), elevated water level and surface outlet (L)), time period (reference period 1993-2013 (Ref), medium term 2036-2065 (m), long term 2066-2095 (1)), climate scenario (historical RCM simulation (RCM), RCP4.5 (rcp45) RCP8.5 (rcp85)). The median of the reference metrics is indicated with a dashed line. Statistically significant differences in relation to reference conditions (dark grey) at the 0.05 level or lower are indicated in white. 


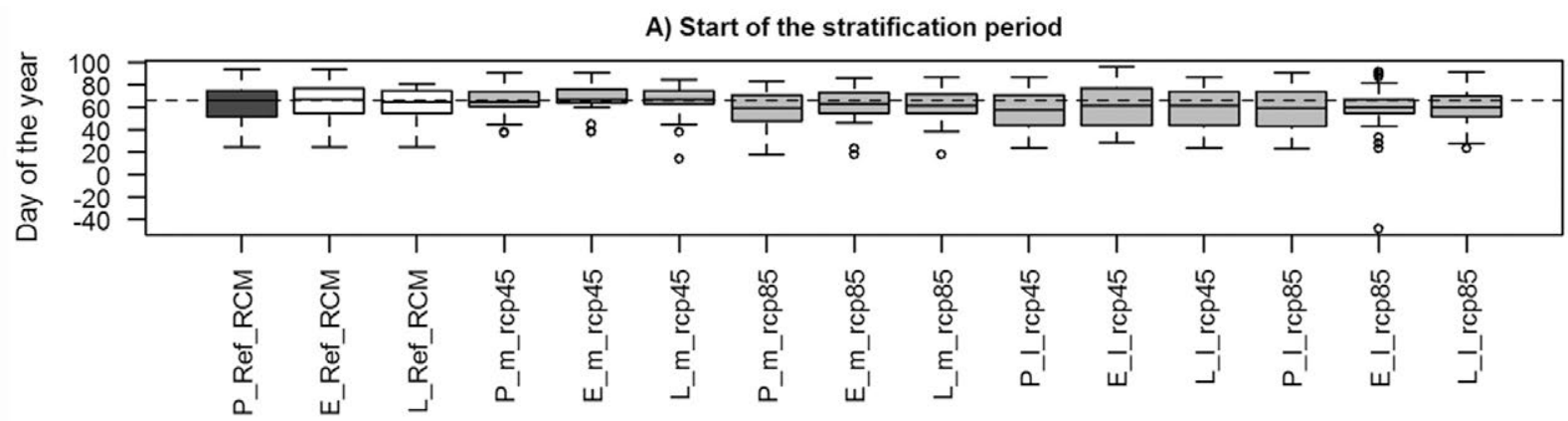

B) End of the stratification period

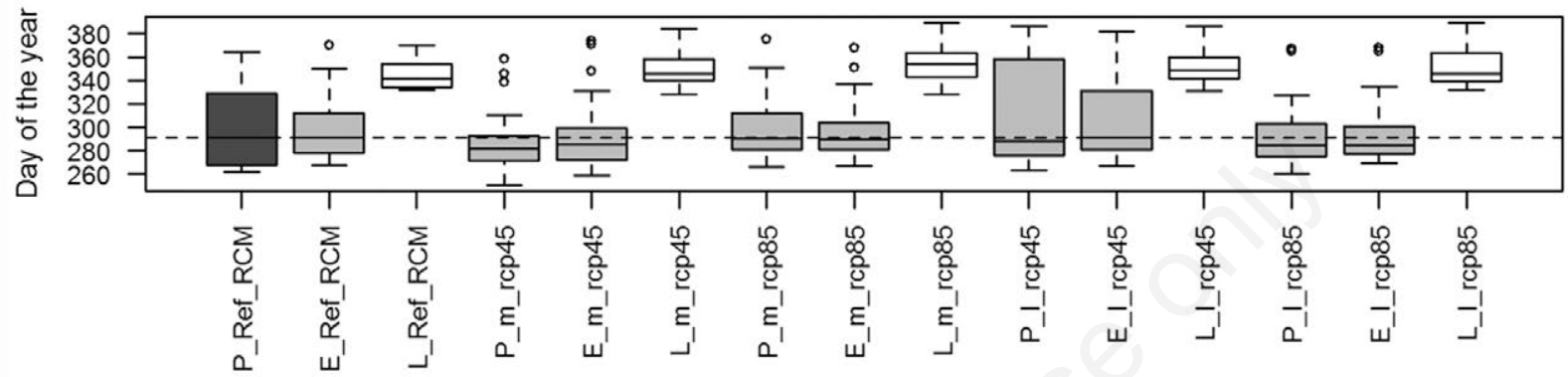

C) Thermocline depth on day 120

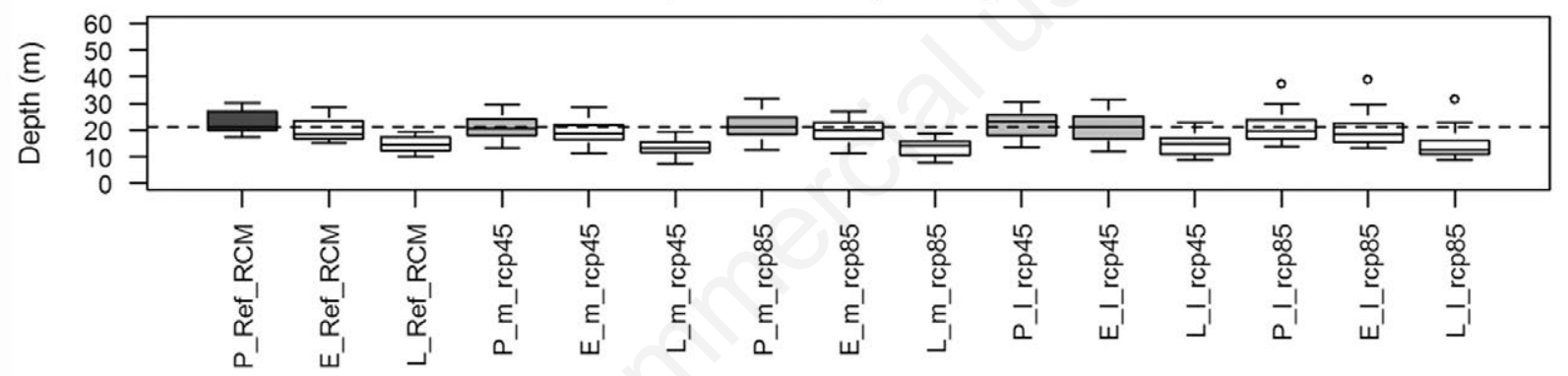

D) Thermocline depth on day 180

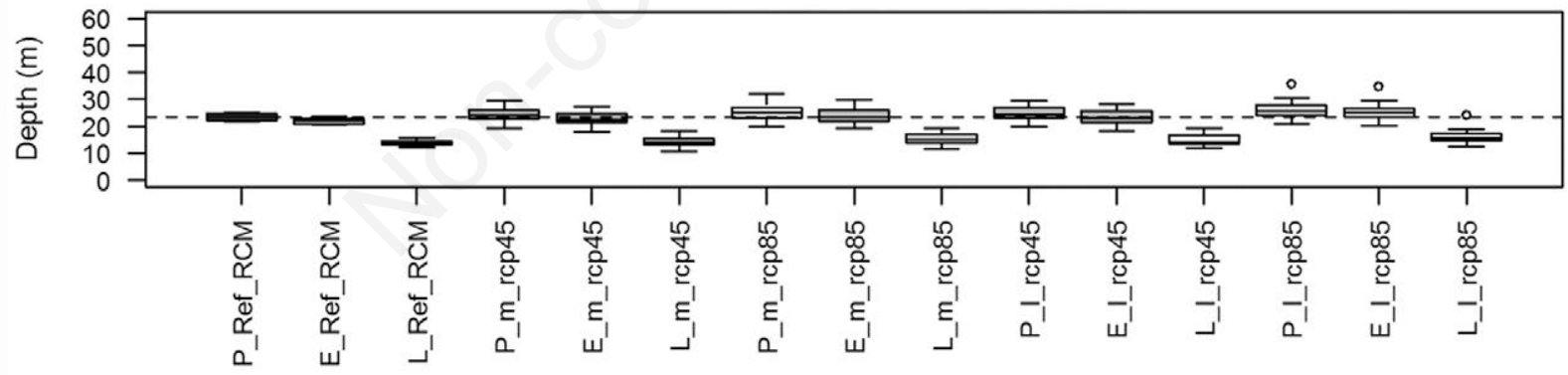

E) Thermocline depth on day 240

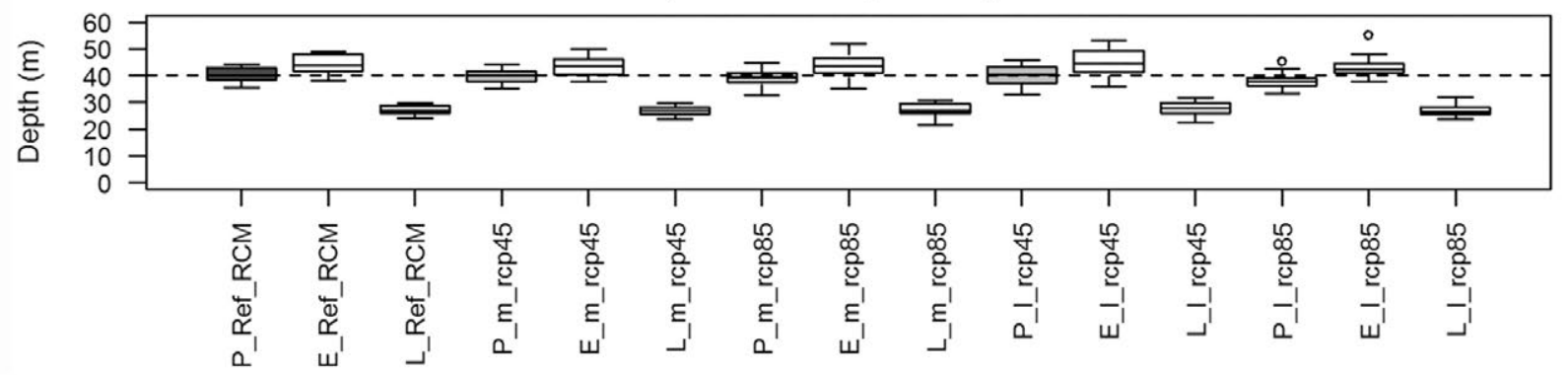

Fig. 8. Stratification metrics under different scenarios (see Fig. 7 caption and Tab. 1 for the meaning of scenario abbreviations). The median of the reference metrics is indicated with a dashed line. Statistically significant differences in relation to reference conditions (dark grey) at the 0.05 level or lower are indicated in white. 
Minimum annual temperatures and the date of start of the stratification period were not affected by the management options considered herein, since these characteristics of the thermal cycle depend mainly on inflow temperature and meteorological factors.

Evaporation was more important in the future scenarios in all cases (Fig. 9). The evaporated volume increased for higher water levels ( $\mathrm{E}$ and $\mathrm{L}$ management strategies) by about $0.008-0.013 \mathrm{~m}^{3} \mathrm{~s}^{-1}$, because of the greater evaporation surface. Evaporation was $0.033-0.034 \mathrm{~m}^{3} \mathrm{~s}^{-1}$ under the L management type, slightly lower than under the $\mathrm{E}$ management type $\left(0.037-0.038 \mathrm{~m}^{3} \mathrm{~s}^{-1}\right)$, because of the lower surface temperatures in L scenarios.

\section{DISCUSSION}

\section{Quality of the hydrodynamic projections}

We predicted the climate change effect on the thermal and hydrodynamic behaviour of the reservoir of Bimont using a model-based approach. Since models are just approximations of the real systems, explicitly stating the model limitations and uncertainties is essential to avoid overconfidence in simulation results (Boschetti et al., 2011; Gal et al., 2014). We consider herein the uncertainties linked to the model, including both its structure and calibration, and to the input data.

EOLE was capable to reproduce well the thermo-hydrodynamic behaviour of the reservoir of Bimont. The observed bias of EOLE simulations in the calibration and validation periods are in the range of those found in the literature for 1D hydrodynamic models (Perroud et al., 2009; Stepanenko et al., 2010; Stepanenko et al., 2013; Stepanenko et al., 2014). EOLE belongs to a class of integral energy models, which also includes models such as
DYRESM (Imberger and Patterson, 1981; Antenucci and Imerito, 2000), GLM (Hipsey et al., 2014) and Minlake (Riley and Stefan, 1988). The structure of this class of models, physically based and including the main thermodynamic processes, has been tested in many study cases and proved to simulate the hydrodynamic behaviour of lakes and reservoirs with sufficient accuracy (Salençon, 1997; Gal et al., 2003; Yao et al., 2014).

The model's calibrated parameter values provide stable simulations in the long term, with a quality comparable to that of the calibration period, as shown by the comparison between surface temperature simulations and satellite measurements in the reference period (Fig. 4). When using short periods of data for calibration, it is possible to incur in the overcalibration problem, obtaining an optimum parameter set that results in worse simulations when applied to periods other than the calibration period (Dahl and Wilson, 2006; Andréassian et al., 2012). Sometimes, simulation results can also look good during the validation period, but worse results are obtained if the same parameter values are applied to a longer time period or different validation period (Andréassian et al., 2012). This was actually observed during the calibration process. A promising parameter value set according to the 2010 2011 calibration period and the 2012-2014 validation period was discarded after finding overshoots in simulated surface temperature for the 1993-2013 validation period. Using long data periods for the validation of model parameter sets is then essential, especially for long term simulations as those found in climate change studies. When in situ data is scarce, satellite images are a convenient way of obtaining long term data series of surface water temperature (Schneider and Hook, 2010; Sharma et al., 2015).

The artificial inflow data used for the reference period simulations and the different scenarios has a lower daily

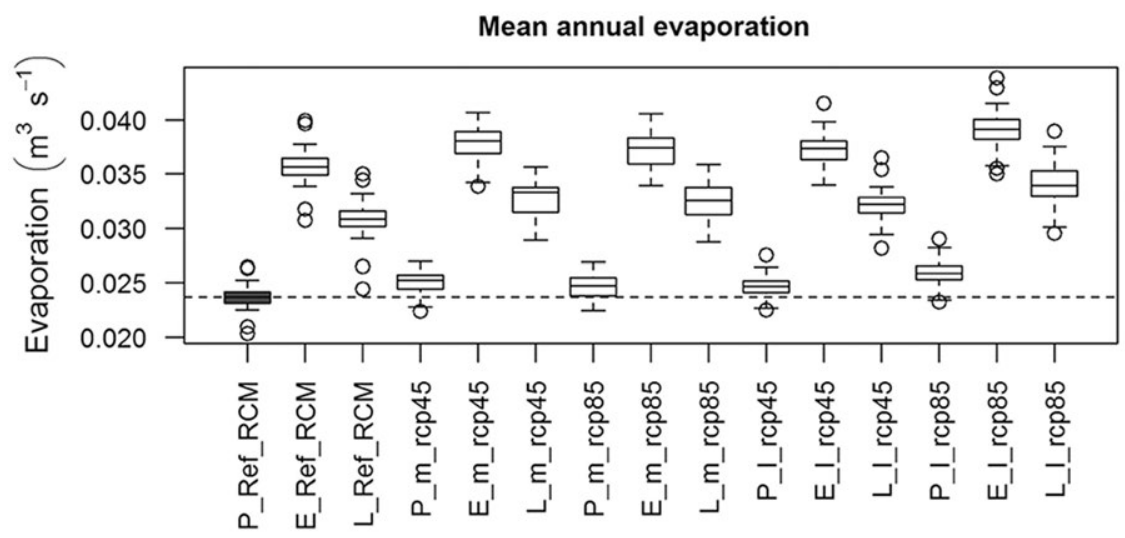

Fig. 9. Evaporation under different scenarios (see Fig. 7 caption and Tab. 1 for the meaning of scenario abbreviations). The median of the reference metrics is indicated with a dashed line. Statistically significant differences in relation to reference conditions (dark grey) at the 0.05 level or lower are indicated in white. 
variability than that of the calibration and validation periods. For the reference period we used interpolated monthly data, while for the projections we estimated the annual cycle through a sinusoid (with small modifications to compensate for variations in precipitation, evaporation and natural inflow and maintain a constant water level). To assess whether the lower daily variability could have an important effect on the reservoir hydrodynamics and thermal behaviour we compared simulations using daily data and monthly data for the artificial inflow. The only important differences occurred below the outlet depth during certain years at the end of the stratification period. At this time of the year particularly high flows on punctual days might induce a breaking of the stratification that would not occur if daily flows were equal to the monthly values. The autumn overturn may thus be delayed because of the lower daily flow variability and the end of the stratification period predicted in the different scenarios may be overestimated. Since all scenarios are forced by the same type of artificial inflows, there should not be an effect on the general trends.

The RCM data used to force the climate simulations showed biases in the seasonal distribution of solar radiation, wind speed and relative humidity (Fig. 5). Although climate models continue to improve through an increase in resolution and complexity, some biases still occur (Flato et al., 2013). In the case of the model CNRMCM5.1, the quality or air temperature and air pressure has improved, but there are major errors in the seasonal distribution of precipitation and cloud radiative forcing (Voldoire et al., 2013). Although the quantile-quantile correction corrects average bias and the spread of the RCM simulations, it cannot correct the temporal autocorrelation properties of the series, including the seasonal cycle of the meteorological variables (Boé et al., 2007; Déqué, 2007). The application of an independent quantile-quantile correction for each season might improve the simulation results (Boé et al., 2007), but we discarded this option given the relatively short (21 years) data series available to obtain the empirical distribution functions of the meteorological variables and the relatively unimportant effect of these biases (Tab. 2).

The climate model slightly overestimated solar radiation from April to August, but this overestimation had little relevance on the hydrodynamic simulations. A constant increase in solar radiation of $15 \mathrm{~W} \cdot \mathrm{m}^{-2}$ in those months for 2010-2011 affected mainly epilimnion temperatures, producing an increase in epilimnion temperature of a maximum of $0.5^{\circ} \mathrm{C}$ in May. After this peak, the temperature difference decreased. The excess heat was lost mainly through increased evaporation, given that thermocline depth only increased by $1 \mathrm{~m}$ by day 240 of the year (end of August). The higher water temperatures induced an increase in mean annual evaporation of $0.007 \mathrm{~m}^{3} \mathrm{~s}^{-1}$. Since the alteration started after the period of minimum water temperatures in February, minimum epilimnion temperatures were not affected either. The effect on the mean epilimnion temperature was about $0.1^{\circ} \mathrm{C}$ and it was $0.2^{\circ} \mathrm{C}$ on maximum annual water temperature. The effect on mean and maximum annual hypolimnion temperature was less than $0.1^{\circ} \mathrm{C}$

The effect of the modification of the annual cycle of relative humidity by the climate model was still less important than the effect of the modification in solar radiation, according to a test consisting in increasing relative humidity by $4 \%$ from January to June and decreasing it by $4 \%$ from July to December for 2010-2011. The only relevant effect was a decrease of maximum annual temperature by $0.1-0.2^{\circ} \mathrm{C}$ because of the increase of evaporation in the summer.

The accurate prediction of wind speed is important because of its influence on lake hydrodynamics (Bayer et al., 2013). The wind speed simulations did not show a clear trend. This contrasts with an average decreasing trend of $-0.014 \mathrm{~m} \mathrm{~s}^{-1} \mathrm{yr}^{-1}$ in the world determined from a meta-analysis of 148 studies and an average trend of $0.010 \mathrm{~m} \mathrm{~s}^{-1} \mathrm{yr}^{-1}$ in Europe for 1979-2008 (McVicar et al., 2012). The effect of wind on hydrodynamics is expected to be small by the mid-2 $1^{\text {st }}$ century in the US (Butcher et al., 2015). According to Christensen et al. (2007) there is little confidence in projected wind speeds and a reduction of wind speed of about $5 \%$ would be expected by the end of the century in the study area. This difficulty in simulating wind speed is an important challenge to predicting the effects of climate change on lake hydrodynamics (Mooij et al., 2010).

\section{Expected climate change effect}

Climate change effects on the hydrodynamics of the reservoir of Bimont will be small according to our simulations. Mean annual surface water temperature at the reservoir of Bimont is expected to increase at a rate of $0.009-0.024^{\circ} \mathrm{C} \mathrm{yr}^{-1}$. This trend is lower than observed or predicted by others (Komatsu et al., 2007; Dokulil, 2014; Butcher et al., 2015) and corresponds to the lower range of the observed lake warming rates (Kraemer et al., 2015; O'Reilly et al., 2015). Because of the higher surface temperatures, evaporation is expected to increase by about $12-16 \%$ at Bimont. However, the effect is of little relevance in comparison with inflow volume and with other studies. For example, Hondzo and Stefan (1991) found an increase in water lost by evaporation of about $40 \%$ between 1988 and 1971.

Lake warming rates are geographically variable and depend on the interaction of several factors, such as latitude, depth and average temperature (Butcher et al., 2015; Kraemer et al., 2015; O'Reilly et al., 2015). In reservoirs, climatic warming trends can be modified by hydraulic 
management (Moreno-Ostos et al., 2008; Kerimoglu and Rinke, 2013). Important warming rates may appear because of the reduction of the cloud cover, resulting in higher temperatures and incoming solar radiation (O’Reilly et al., 2015). As shown in Fig. 5D, no variations in insolation are expected in the future for the reservoir of Bimont. Temperature increases in the reservoir of Bimont will then be related to increases in air temperature and inflow temperature.

Mean annual hypolimnion temperature is expected to increase at a rate of $0.013-0.028^{\circ} \mathrm{C} \mathrm{yr}^{-1}$ at Bimont reservoir. This is unexpected, since hypolimnion temperatures tend to respond less strongly to meteorological conditions than epilimnion temperatures (Hondzo and Stefan, 1991). Actually, Kraemer et al. (2015) found an average hypolimnion warming of $0.05^{\circ} \mathrm{C}$ in 26 lakes over the world for 19702010, a trend one order of magnitude lower. Still, future increases in hypolimnion temperature depend on lake morphology and depth (Gerten and Adrian, 2002; Danis et al., 2004; Butcher et al., 2015). Increases in bottom water temperature are greater in shallow lakes (Butcher et al., 2015). In a reservoir, deep outlets increase the mixing rates and decrease the overall stability of the water column, with a higher transport of heat to the lower layers. So, hypolimnion temperatures in reservoirs should be more sensitive to meteorological forcing than in natural lakes.

Additionally, the annual average hypolimnion temperature depends on the winter meteorological conditions (Straile et al., 2003). At the study area, the most important air temperature increases are expected to occur in the months of November, December and January, when the water column is fully mixed (Fig. 5B). Kirillin (2010) also found a more important warming in winter for two Berlin lakes. Since minimum temperatures at the reservoir of Bimont occur during the turnover period, usually in February, the higher air temperature warming rate in the previous months can explain that minimum temperatures increase quicker than maximum temperatures.

A general trend towards a more stable stratification has been observed in world lakes (Kraemer et al., 2015). Also, the lengthening of the stratification period and higher stability has been predicted for many lakes (Danis et al., 2004; Fang and Stefan, 2009; Bayer et al., 2013; Gebre et al., 2014; Butcher et al., 2015; Sahoo et al., 2015; etc.). However, the response of stratification patterns to climate shows a higher variability among lakes than the response of surface temperatures (Read et al., 2014). Apart from this study, other studies have found a slight effect of climate change on stratification (Hondzo and Stefan, 1991). Surface temperatures depend on meteorological conditions, while stratification depends on the temperature (and density) jump between the epilimnion and the hypolimnion as well as on morphology and the effect of wind - as parameterized through the
Lake number (Imberger and Patterson, 1989). The faster increase of surface temperatures compared to bottom temperatures has been suggested as the reason for an increase in stability and lengthening of the stratification period in lakes (Livingstone, 2003; Wang et al., 2012). Since epilimnion temperature and hypolimnion temperature trends are similar for the reservoir of Bimont, it seems reasonable that the stability and stratification period do not change in the projected scenarios. In addition, given the great importance of hydraulic management on stratification (Moreno-Ostos et al., 2008), we expect stratification patterns in reservoirs to be less affected by climate.

\section{Effect of different management options}

Climate change will produce an increase in water temperatures in the reservoir of Bimont, independently of the management scenario. The warming of the reservoir can be limited by changing the management strategy. An elevation of water level from $329.5 \mathrm{~m}$ to $340 \mathrm{~m}$ may reduce maximum annual epilimnion temperatures by $\sim 1^{\circ} \mathrm{C}$ (Fig. 7). In lakes the greater surface area and fetch at higher water levels induces a deeper thermocline by favouring the action of wind (Pompilio et al., 1996; Boehrer and Schultze, 2008). In reservoirs, stratification is hydraulically controlled by the depth of the outlet: the deeper the outlet depth, the deeper the thermocline (Han et al., 2000; Casamitjana et al., 2003). Increasing the water depth may also intensify stratification stability (Kerimoglu and Rinke, 2013). By increasing the surface area, evaporation also increases. In the Bimont reservoir, maximum water loss occurs under the E_1 rep85 scenario, when evaporation accounts for about $3 \%$ of throughflow.

In addition to increasing water level, if the extraction depth is changed from the bottom to the surface, maximum annual water temperature decreases by $1.4^{\circ} \mathrm{C}$. With a surface outlet surface, warm water is extracted from the system, reducing heat storage and hypolimnion temperatures, avoiding the deepening of the thermocline (Han et al., 2000; Ma et al., 2008) and increasing the stability of stratification (Kerimoglu and Rinke, 2013). The delayed end of the stratification period under the L management option is probably due to the higher temperature gradient between the epilimnion and the hypolimnion, increasing stability.

This experience has shown that the magnitude of the effects due to changes in management are of the same order of magnitude as climate change effects, which gives an opportunity to develop some management solutions in artificial inland water bodies. We analysed the effect of three simple management scenarios, but more complex management patterns, including extraction at different depths as a function of the time of the year, could be considered, maybe with the improvement of water quality as well as water temperature in mind (Palau, 2006). Different engineering options already existing could be applied to 
control reservoir water temperature by extracting water from different depths (Sherman, 2000).

In this paper we have considered effects on water temperature, stratification dynamics and evaporation only. However, in developing a solution, chemical and biological aspects should also be considered. Using a surface outlet can decrease surface temperatures. This solution can also reduce downstream thermal effects by the dam. But it also means that the renovation time of hypolimnion waters increases greatly with the potential danger of hypoxia. We have not taken into account either the effect of changes in transparency, which can affect the response of lake stratification to climate change (Danis et al., 2004; Butcher et al., 2015). In our case LEC was $0.34 \mathrm{~m}^{-1}$ and since stratification is very sensitive to transparency for low values of the LEC below $0.5 \mathrm{~m}^{-1}$ (Henderson-Sellers, 1988; Heiskanen et al., 2015) potential changes in water transparency could have an important effect on Bimont reservoir hydrodynamics.

\section{CONCLUSIONS}

The reservoir of Bimont will have a low rate of warming of the epilimnion, but a rapid hypolimnion warming, in response to the winter warming in climate scenarios. The increase in surface temperatures will augment evaporation. Unexpectedly, no important climate change effects on stratification are expected. From the thermal viewpoint only, it might be possible to limit the effects of climate change by elevating the water level and/or changing the outlet depth. The most important reductions in water temperatures are obtained when a higher water level is maintained and a surface outlet depth is used.

\section{ACKNOWLEDGMENTS}

We acknowledge the World Climate Research Programme's Working Group on Regional Climate, and the Working Group on Coupled Modelling, former coordinating body of CORDEX and responsible panel for CMIP5. We thank the climate modelling groups SMHI and CNRM-CERFACS for producing and making available their model output. We acknowledge the Earth System Grid Federation infrastructure.

We thank Météo-France and the Société du Canal de Provence for providing essential data for this study, and Brigitte Delmas and Yann Viala for their support. We thank our colleagues Nathalie Reynaud and Yann Le Coarer for their help in preparing the reservoir bathymetry, and Nathalie Reynaud and Thierry Tormos for the optimization of the algorithm of the Landsat images treatment. We thank members of the Onema-Irstea consortium Martin Daufresne, Tiphaine Péroux, Julien Dublon and Delphine Rebière for the acquisition of water temperature and Secchi depth data. The funding for this study was provided by the HYNES research program.

\section{REFERENCES}

Ambrosetti W, Barbanti L, 1999. Deep water warming in lakes: an indicator of climatic change. J. Limnol. 58:1-9.

Ambrosetti W, Barbanti L, Rolla A, 2006. [Il clima dell'areale del Lago Maggiore durante gli ultimi cinquant'anni].[Article in Italian with English abstract] J. Limnol. 62(s1):1-64.

Andréassian V, Le Moine N, Perrin C, Ramos M-H, Oudin L, Mathevet T, Lerat J, Berthet L, 2012. All that glitters is not gold: the case of calibrating hydrological models. Hydrol. Process. 26:2206-2210.

Antenucci J, Imerito A, 2000. The CWR Dynamic Reservoir Simulation Model DYRESM. Science Manual. The University of Western Australia, Perth, Australia.

Arismendi I, Safeeq M, Dunham JB, Johnson SL, 2014. Can air temperature be used to project influences of climate change on stream temperature? Environ. Res. Lett. 9:084015.

Bayer T, Burns C, Schallenberg M, 2013. Application of a numerical model to predict impacts of climate change on water temperatures in two deep, oligotrophic lakes in New Zealand. Hydrobiologia 713:53-71.

Benyahya L, Caissie D, Satish MG, El-Jabi N, 2012. Long-wave radiation and heat flux estimates within a small tributary in Catamaran Brook (New Brunswick, Canada). Hydrol. Process. 26:475-484.

Boé J, Terray L, Habets F, Martin E, 2007. Statistical and dynamical downscaling of the Seine basin climate for hydrometeorological studies. Int. J. Climatol. 27:1643-1655.

Boehrer B, Schultze M, 2008. Stratification of lakes. Rev. Geophys. 46:RG2005.

Boschetti F, Grigg NJ, Enting I, 2011. Modelling = conditional prediction. Ecol. Complex. 8:86-91.

Bustillo V, Moatar F, Ducharne A, Thiéry D, Poirel A, 2014. A multimodel comparison for assessing water temperatures under changing climate conditions via the equilibrium temperature concept: case study of the Middle Loire River, France. Hydrol. Process. 28:1507-1524.

Butcher J, Nover D, Johnson T, Clark C, 2015. Sensitivity of lake thermal and mixing dynamics to climate change. Climatic Change 129:295-305.

Casamitjana X, Serra T, Colomer J, Baserba C, Pérez-Losada J, 2003. Effects of the water withdrawal in the stratification patterns of a reservoir. Hydrobiologia 504:21-28.

Chang LH, Railsback SF, Brown RT, 1992. Use of a reservoir water quality model to simulate global climate change effects on fish habitat. Climatic Change 20:277-296.

Christensen JH, Hewitson B, Busuioc A, Chen A, Gao X, Held I, Jones R, Kolli RK, Kwon W-T, Laprise R, Magaña Rueda V, Mearns L, Menéndez CG, Räisänen J, Rinke A, Sarr A, Whetton P, 2007. Regional Climate Projections, p. 847-940. In: S. Solomon, D. Qin, M. Manning, Z. Chen, M. Marquis, K.B. Averyt, M. Tignor and H.L. Miller (eds.), Climate change 2007: The Physical science basis. Contribution of Working Group I to the Fourth Assessment Report of the Intergovernmental Panel on Climate Change. Cambridge University Press, Cambridge. 
Cid N, Ibáñez C, Prat N, 2008. Life history and production of the burrowing mayfly Ephoron virgo (Olivier, 1791) (Ephemeroptera: Polymitarcyidae) in the lower Ebro river: a comparison after 18 years. Aquat. Insect. 30:163-178.

Dahl M, Wilson DI, 2006. The danger of short-term validation for lake models. Int. J. Model. Simul. 26:98-105.

Danis P-A, von Grafenstein U, Masson-Delmotte V, Planton S, Gerdeaux D, Moisselin JM, 2004. Vulnerability of two European lakes in response to future climatic changes. Geophys. Res. Lett. 31:L21507.

Daufresne M, Boet P, 2007. Climate change impacts on structure and diversity of fish communities in rivers. Glob. Change Biol. 13:2467-2478.

Déqué M, 2007. Frequency of precipitation and temperature extremes over France in an anthropogenic scenario: Model results and statistical correction according to observed values. Global Planet. Change 57:16-26.

Dokulil M, 2014. Predicting summer surface water temperatures for large Austrian lakes in 2050 under climate change scenarios. Hydrobiologia 731:19-29.

Dutordoir S, 2010. [Modélisation thermodynamique de la retenue Bimont à l'aide du modèle DYRESM].[Report in French]. Pôle Onema-Irstea, Université Pierre et Marie Curie, Mines ParisTech, AgroParisTech, Paris, France.

Fang X, Alam SR, Stefan HG, Jiang L, Jacobson PC, Pereira DL, 2012. Simulations of water quality and oxythermal cisco habitat in Minnesota lakes under past and future climate scenarios. Water Qual. Res. J. Can. 47:375-388.

Fang X, Stefan HG, 1994. Modeling of dissolved oxygen stratification dynamics in Minnesota lakes under different climate scenarios, p. 223. St. Anthony Falls Hydraulic Laboratory, University of Minnesota, Minneapolis.

Fang X, Stefan HG, 2009. Simulations of climate effects on water temperature, dissolved oxygen, and ice and snow covers in lakes of the contiguous United States under past and future climate scenarios. Limnol. Oceanogr. 54:2359-2370.

Flato G, Marotzke J, Abiodun B, Braconnot P, Chou SC, Collins W, Cox P, Driouech F, Emori S, Eyring V, Forest C, Glecker P, Guilyardi E, Jakob C, Kattsov V, Reason C, Rummukainen M, 2013. Evaluation of Climate Models, p. 741866. In: T.F. Stocker, D. Qin, G.-K. Plattner, M.M.B. Tignor, S.K. Allen, J. Boschung, A. Nauels, Y. Xia, V. Bex and P.M. Midgley (eds.), Climate change 2013: The Physical basis. Contribution of Working Group I to the Fifth Assessment Report of the Intergovernmental Panel on Climate Change. Cambridge University Press, Cambridge, UK and New York, NY, USA.

Gal G, Hipsey M, Rinke K, Robson B, 2014. Novel approaches to address challenges in modelling aquatic ecosystems. Environ. Modell. Softw. 61:246-248.

Gal G, Imberger J, Zohary T, Antenucci J, Anis A, Rosenberg T, 2003. Simulating the thermal dynamics of Lake Kinneret. Ecol. Model. 162:69-86.

Gasith A, Resh VH, 1999. Streams in Mediterranean climate regions: Abiotic influences and biotic responses to predictable seasonal events. Annu. Rev. Ecol. Syst. 30:51-81.

Gebre S, Boissy T, Alfredsen K, 2014. Sensitivity to climate change of the thermal structure and ice cover regime of three hydropower reservoirs. J. Hydrol. 510:208-227.

Georgakakos AP, Yao H, Kistenmacher M, Georgakakos KP,
Graham NE, Cheng FY, Spencer C, Shamir E, 2012. Value of adaptive water resources management in Northern California under climatic variability and change: Reservoir management. J. Hydrol. 412-413:34-46.

Gerten D, Adrian R, 2002. Effects of climate warming, North Atlantic Oscillation, and El Niño-Southern Oscillation on Thermal conditions and plankton dynamics in northern hemispheric lakes. Sci. World J. 2:586-606.

Giorgi F, Jones C, Asrar GR, 2009. Addressing climate information needs at the regional level: the CORDEX framework. WMO Bull. 58:175-183.

Gosse P, Gailhard J, Hendrickx F, 2008. [Analyse de la température de la Loire moyenne en été sur la période 1949 à 2003].[Article in French]. Hydroecol. Appl. 16:233-274.

Han B-P, Armengol J, Garcia JC, Comerma M, Roura M, Dolz J, Straskraba M, 2000. The thermal structure of Sau Reservoir (NE: Spain): a simulation approach. Ecol. Model. 125:109-122.

Heiskanen JJ, Mammarella I, Ojala A, Stepanenko V, Erkkilä KM, Miettinen H, Sandström H, Eugster W, Leppäranta M, Järvinen H, Vesala T, Nordbo A, 2015. Effects of water clarity on lake stratification and lake-atmosphere heat exchange. J. Geophys. Res.-Atmos. 120:7412-7428.

Henderson-Sellers B, 1988. Sensitivity of thermal stratification models to changing boundary conditions. Appl. Math. Model. 12:31-43.

Hetherington AL, Schneider RL, Rudstam LG, Gal G, DeGaetano AT, Walter MT, 2015. Modeling climate change impacts on the thermal dynamics of polymictic Oneida Lake, New York, United States. Ecol. Model. 300:1-11.

Hipsey MR, Bruce LC, Hamilton DP, 2014. GLM - General Lake Model: Model overview and user information. University of Western Australia, Perth: 42 pp.

Hondzo M, Stefan HG, 1991. Three case studies of lake temperature and stratification response to warmer climate. Water Resour. Res. 27:1837-1846.

Imberger J, Patterson J, 1981. A Dynamic Reservoir Simulation Model - DYRESM: 5, p. 310-361. In: H.B. Fischer (ed.), Transport models for inland and coastal waters. Academic Press, New York.

Imberger J, Patterson JC, 1989. Physical limnology. Adv. Appl. Mech. 27:303-475.

Jiménez-Muñoz JC, Cristóbal J, Sobrino JA, Sòria G, Ninyerola M, Pons X, 2009. Revision of the single-channel algorithm for land surface temperature retrieval from Landsat thermalinfrared data. IEEE T. Geosci. Remote 47:339-349.

Kerimoglu O, Rinke K, 2013. Stratification dynamics in a shallow reservoir under different hydro-meteorological scenarios and operational strategies. Water Resour. Res. 49:7518-7527.

Kirillin G, 2010. Modeling the impact of global warming on water temperature and seasonal mixing regimes in small temperate lakes. Boreal Env. Res. 15:279-293.

Koch H, Grünewald U, 2010. Regression models for daily stream temperature simulation: case studies for the river Elbe, Germany. Hydrol. Process. 24:3826-3836.

Komatsu E, Fukushima T, Harasawa H, 2007. A modeling approach to forecast the effect of long-term climate change on lake water quality. Ecol. Model. 209:351-366.

Kraemer BM, Anneville O, Chandra S, Dix M, Kuusisto E, Livingstone DM, Rimmer A, Schladow SG, Silow E, Sitoki LM, 
Tamatamah R, Vadeboncoeur Y, McIntyre PB, 2015. Morphometry and average temperature affect lake stratification responses to climate change. Geophys. Res. Lett. 42:49814988.

Kupiainen M, Jansson C, Samuelsson P, Jones C, Willén U, Hansson U, Wang S, Döscher R, 2011. Rossby Centre regional atmospheric model, RCA 4. Rossby Centre Newsletter.

Li L, Xu H, Chen X, Simonovic SP, 2009. Streamflow Forecast and Reservoir Operation Performance Assessment Under Climate Change. Water Resour. Manage. 24:83.

Livingstone DM, 2003. Impact of secular climate change on the thermal structure of a large temperate central European lake. Climatic Change 57:205-225.

Ma S, Kassinos SC, Fatta Kassinos D, Akylas E, 2008. Effects of selective water withdrawal schemes on thermal stratification in Kouris Dam in Cyprus. Lakes Reserv. Res. Manag. 13:51-61.

Marcé R, Moreno-Ostos E, García-Barcina JM, Armengol J, 2010. Tailoring dam structures to water quality predictions in new reservoir projects: Assisting decision-making using numerical modeling. J. Environ. Manage. 91:1255-1267.

McVicar TR, Roderick ML, Donohue RJ, Li LT, Van Niel TG, Thomas A, Grieser J, Jhajharia D, Himri Y, Mahowald NM, Mescherskaya AV, Kruger AC, Rehman S, Dinpashoh Y, 2012. Global review and synthesis of trends in observed terrestrial near-surface wind speeds: Implications for evaporation. J. Hydrol. 416-417:182-205.

Missaghi S, Hondzo M, Herb W, 2017. Prediction of lake water temperature, dissolved oxygen, and fish habitat under changing climate. Climatic Change 141:747-757.

Mohseni O, Erickson TR, Stefan HG, 1999. Sensitivity of stream temperatures in the United States to air temperatures projected under a global warming scenario. Water Resour. Res. 35:3723-3733.

Mohseni O, Stefan HG, Erickson TR, 1998. A nonlinear regression model for weekly stream temperatures. Water Resour. Res. 34:2685-2692.

Mooij W, Trolle D, Jeppesen E, Arhonditsis G, Belolipetsky PV, Chitamwebwa DBR, Degermendzhy AG, DeAngelis DL, De Senerpont Domis LN, Downing AS, Elliott JA, Fragoso CR, Jr, Gaedke U, Genova SN, Gulati RD, Håkanson L, Hamilton DP, Hipsey MR, ‘t Hoen J, Hülsmann S, Los FH, Makler-Pick V, Petzoldt T, Prokopkin IG, Rinke K, Schep SA, Tominaga K, Van Dam AA, Van Nes EH, Wells SA, Janse JH, 2010. Challenges and opportunities for integrating lake ecosystem modelling approaches. Aquat. Ecol. 44:633-667.

Moreno-Ostos E, Marce R, Ordonez J, Dolz Ripolles J, Armengol J, 2008. Hydraulic management drives heat budgets and temperature trends in a Mediterranean reservoir. Int. Rev. Hydrobiol. 93:131-147.

O'Reilly CM, Sharma S, Gray DK, Hampton SE, Read JS, Rowley RJ, Schneider P, Lenters JD, McIntyre PB, Kraemer BM, Weyhenmeyer GA, Straile D, Dong B, Adrian R, Allan MG, Anneville O, Arvola L, Austin J, Bailey JL, Baron JS, Brookes JD, de Eyto E, Dokulil MT, Hamilton DP, Havens $\mathrm{K}$, Hetherington AL, Higgins SN, Hook S, Izmest'eva LR, Joehnk KD, Kangur K, Kasprzak P, Kumagai M, Kuusisto E, Leshkevich G, Livingstone DM, MacIntyre S, May L, Melack JM, Mueller-Navarra DC, Naumenko M, Noges P, Noges T, North RP, Plisnier P-D, Rigosi A, Rimmer A, Rogora M, Rudstam LG, Rusak JA, Salmaso N, Samal NR,
Schindler DE, Schladow SG, Schmid M, Schmidt SR, Silow E, Soylu ME, Teubner K, Verburg P, Voutilainen A, Watkinson A, Williamson CE, Zhang G, 2015. Rapid and highly variable warming of lake surface waters around the globe. Geophys. Res. Lett. 42:10773-10781.

Palau A, 2006. Integrated environmental management of current reservoirs and regulated rivers. Limnetica 25:287-302.

Patterson JC, Hamblin PF, Imberger J, 1984. Classification and dynamic simulation of the vertical density structure of lakes. Limnol. Oceanogr. 29:845-861.

Perrin C, Michel C, Andréassian V, 2003. Improvement of a parsimonious model for streamflow simulation. J. Hydrol. 279:275-289.

Perroud M, Goyette S, Martynov A, Beniston M, Anneville O, 2009. Simulation of multiannual thermal profiles in deep Lake Geneva: A comparison of one-dimensional lake models. Limnol. Oceanogr. 54:1574-1594.

Pompilio L, Ambrosetti W, Barbanti L, 1996. Morphometry and thermal stratification in Italian lakes. 1. Predictive models. Mem. Ist. Ital. Idrobiol. 54:1-29.

Quintana-Seguí P, Le Moigne P, Durand Y, Martin E, Habets F, Baillon M, Canellas C, Franchisteguy L, Morel S, 2008. Analysis of Near-Surface Atmospheric Variables: Validation of the SAFRAN analysis over France. J. Appl. Meteorol. 47:92-107.

Raje D, Mujumdar PP, 2010. Reservoir performance under uncertainty in hydrologic impacts of climate change. Adv. Water Res. 33:312-326.

Read JS, Winslow LA, Hansen GJA, Van Den Hoek J, Hanson PC, Bruce LC, Markfort CD, 2014. Simulating 2368 temperate lakes reveals weak coherence in stratification phenology. Ecol. Model. 291:142-150.

Rheinheimer DE, Null SE, Lund JR, 2015. Optimizing selective withdrawal from reservoirs to manage downstream temperatures with climate warming. J. Water Resour. Plann. Manage. DOI: doi.org/10.1061/(ASCE)WR.1943-5452.0000447

Riley MJ, Stefan HG, 1988. Minlake: A dynamic lake water quality simulation model. Ecol. Model. 43:155-182.

Robson BJ, 2014. When do aquatic systems models provide useful predictions, what is changing, and what is next? Environ. Modell. Softw. 61:287-296.

Rübbelke D, Vögele S, 2011. Impacts of climate change on European critical infrastructures: The case of the power sector. Environ. Sci. Policy 14:53-63.

Sahoo GB, Forrest AL, Schladow SG, Reuter JE, Coats R, Dettinger M, 2015. Climate change impacts on lake thermal dynamics and ecosystem vulnerabilities. Limnol. Oceanogr. 61:496-507.

Salençon M-J, 1997. Study of the thermal dynamics of two dammed lakes (Pareloup and Rochebut, France), using the EOLE model. Ecol. Model. 104:15-38.

Salençon M-J, Thébault J-M, 1997. [Modélisation d'écosystème lacustre].[Book in French]. Masson, Paris.

Samuelsson P, Jones CG, Willén U, Ullerstig A, Gollvik S, Hansson ULF, Jansson C, Kjellström E, Nikulin G, Wyser K, 2011. The Rossby Centre Regional Climate model RCA3: model description and performance. Tellus A 63:4-23.

Schindler DW, 1997. Widespread effects of climatic warming on freshwater ecosystems in North America. Hydrol. Process. 11:1043-1067. 
Schneider P, Hook SJ, 2010. Space observations of inland water bodies show rapid surface warming since 1985. Geophys. Res. Lett. 37:n/a-n/a.

Sharma S, Gray DK, Read JS, O'Reilly CM, Schneider P, Qudrat A, Gries C, Stefanoff S, Hampton SE, Hook S, Lenters JD, Livingstone DM, McIntyre PB, Adrian R, Allan MG, Anneville O, Arvola L, Austin J, Bailey J, Baron JS, Brookes J, Chen Y, Daly R, Dokulil M, Dong B, Ewing K, de Eyto E, Hamilton D, Havens K, Haydon S, Hetzenauer H, Heneberry J, Hetherington AL, Higgins SN, Hixson E, Izmest'eva LR, Jones BM, Kangur K, Kasprzak P, Köster O, Kraemer BM, Kumagai M, Kuusisto E, Leshkevich G, May L, MacIntyre S, Müller-Navarra D, Naumenko M, Noges P, Noges T, Niederhauser P, North RP, Paterson AM, Plisnier P-D, Rigosi A, Rimmer A, Rogora M, Rudstam L, Rusak JA, Salmaso N, Samal NR, Schindler DE, Schladow G, Schmidt SR, Schultz T, Silow EA, Straile D, Teubner K, Verburg P, Voutilainen A, Watkinson A, Weyhenmeyer GA, Williamson CE, Woo KH, 2015. A global database of lake surface temperatures collected by in situ and satellite methods from 1985-2009. Sci. Data 2:150008.

Sherman B, 2000. Scoping options for mitigating cold water discharges from dams. CSIRO Land and Water, Canberra.

Simon RN, Tormos T, Danis P-A, 2014. Retrieving water surface temperature from archive LANDSAT thermal infrared data: Application of the mono-channel atmospheric correction algorithm over two freshwater reservoirs. Int. J. Appl. Earth Obs. 30:247-250.

Société du Canal de Provence, 2013. [Étude de l'optimisation de la cote de RN du barrage de Bimont].[Report in French]. Société du Canal de Provence, Le Tholonet.

Stepanenko V, Jöhnk KD, Machulskaya E, Perroud M, Subin Z, Nordbo A, Mammarella I, Mironov D, 2014. Simulation of surface energy fluxes and stratification of a small boreal lake by a set of one-dimensional models. Tellus A 66:1-18.

Stepanenko VM, Goyette S, Martynov A, Perroud M, Fang X, Mironov D, 2010. First steps of a lake Model Intercomparison Project: LakeMIP. Boreal Env. Res. 15:191-202.

Stepanenko VM, Martynov A, Jöhnk KD, Subin ZM, Perroud M, Fang X, Beyrich F, Mironov D, Goyette S, 2013. A onedimensional model intercomparison study of thermal regime of a shallow, turbid midlatitude lake. Geosci. Model Dev. 6:1337-1352.

Straile D, Jöhnk K, Henno R, 2003. Complex effects of winter warming on the physicochemical characteristics of a deep lake. Limnol. Oceanogr. 48:1432-1438.

Trolle D, Elliott JA, Mooij WM, Janse JH, Bolding K, Hamilton DP, Jeppesen E, 2014. Advancing projections of phytoplankton responses to climate change through ensemble modelling. Environ. Modell. Softw. 61:371-379.

Van Straten GT, Keesman KJ, 1991. Uncertainty propagation and speculation in projective forecasts of environmental change: A lake-eutrophication example. J. Forecasting 10:163-190.

van Vuuren D, Edmonds J, Kainuma M, Riahi K, Thomson A, Hibbard K, Hurtt G, Kram T, Krey V, Lamarque J-F, Masui T, Meinshausen M, Nakicenovic N, Smith S, Rose S, 2011. The representative concentration pathways: an overview. Climatic Change 109:5-31.

Vidal J-P, Martin E, Franchistéguy L, Baillon M, Soubeyroux JM, 2010. A 50-year high-resolution atmospheric reanalysis over France with the Safran system. Int. J. Climatol. 30:1627-1644.

Voldoire A, Sanchez-Gomez E, Salas y Mélia D, Decharme B, Cassou C, Sénési S, Valcke S, Beau I, Alias A, Chevallier M, Déqué M, Deshayes J, Douville H, Fernandez E, Madec G, Maisonnave E, Moine MP, Planton S, Saint-Martin D, Szopa S, Tyteca S, Alkama R, Belamari S, Braun A, Coquart L, Chauvin F, 2013. The CNRM-CM5.1 global climate model: description and basic evaluation. Clim. Dyn. 40:2091-2121.

Wang S, Qian X, Han B-P, Luo L-C, Hamilton DP, 2012. Effects of local climate and hydrological conditions on the thermal regime of a reservoir at Tropic of Cancer, in southern China. Water Res. 46:2591-2604.

Weinberger S, Vetter M, 2012. Using the hydrodynamic model DYRESM based on results of a regional climate model to estimate water temperature changes at Lake Ammersee. Ecol. Model. 244:38-48.

Yao H, Samal NR, Joehnk KD, Fang X, Bruce LC, Pierson DC, Rusak JA, James A, 2014. Comparing ice and temperature simulations by four dynamic lake models in Harp Lake: past performance and future predictions. Hydrol. Process. 28:4587-4601.

Yvon-Durocher G, Caffrey JM, Cescatti A, Dossena M, Giorgio Pd, Gasol JM, Montoya JM, Pumpanen J, Staehr PA, Trimmer M, Woodward G, Allen AP, 2012. Reconciling the temperature dependence of respiration across timescales and ecosystem types. Nature 487:472-476. 